\title{
Review
}

Neuro[mmunoModulation

Neuroimmunomodulation 2018;25:246-270

DOI: 10.1159/000494761
Received: May 24, 2018

Accepted after revision: October 17, 2018

Published online: December 5, 2018

\section{Neuroimmune and Inflammatory Signals in Complex Disorders of the Central Nervous System}

\author{
Ana Clara Liberman ${ }^{a}$ Emiliano Trias $^{b}$ Luana da Silva Chagas ${ }^{c}$ Pablo Trindade $^{d}$ \\ Marissol dos Santos Pereira $^{e, f}$ Damian Refojo ${ }^{a} \quad$ Cecilia Hedin-Pereira $^{\mathrm{e}-\mathrm{g}}$
}

Claudio A. Serfaty ${ }^{c}$

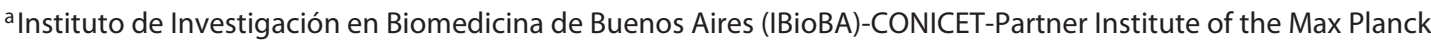
Society, Buenos Aires, Argentina; ${ }^{b}$ Neurodegeneration Laboratory, Institut Pasteur de Montevideo, Montevideo,

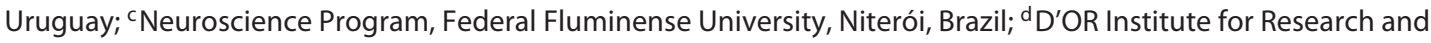

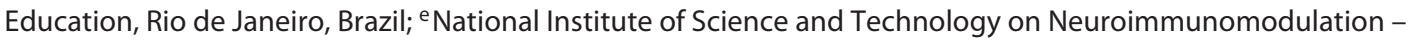
INCT-NIM, Oswaldo Cruz Institute, Oswaldo Cruz Foundation, Rio de Janeiro, Brazil; f Laboratory for Cellular NeuroAnatomy, Institute for Biomedical Sciences, Federal University of Rio de Janeiro, Rio de Janeiro, Brazil; ${ }^{9}$ VPPCB, Fiocruz, Rio de Janeiro, Brazil

\section{Keywords}

Microglia · Astrocyte · Cytokine · Autism · Depression · Amyotrophic lateral sclerosis · Lesion-induced plasticity · Neuroinflammation · Neurodegeneration

\begin{abstract}
An extensive microglial-astrocyte-monocyte-neuronal cross talk seems to be crucial for normal brain function, development, and recovery. However, under certain conditions neuroinflammatory interactions between brain cells and neuroimmune cells influence disease outcome and brain pathology. Microglial cells express a range of functional states with dynamically pleomorphic profiles from a surveilling status of synaptic transmission to an active player in major events of development such as synaptic elimination, regeneration, and repair. Also, inflammation mediates a series of neurotoxic roles in neuropsychiatric conditions and neurodegenerative diseases. The present review discusses data on the involvement of neuroinflammatory conditions that alter
\end{abstract}

\section{KARGER}

(c) 2018 S. Karger AG, Basel

E-Mail karger@karger.com

www.karger.com/nim neuroimmune interactions in four different pathologies. In the first section of this review, we discuss the ability of the early developing brain to respond to a focal lesion with a rapid compensatory plasticity of intact axons and the role of microglial activation and proinflammatory cytokines in brain repair. In the second section, we present data of neuroinflammation and neurodegenerative disorders and discuss the role of reactive astrocytes in motor neuron toxicity and the progression of amyotrophic lateral sclerosis. In the third section, we discuss major depressive disorders as the consequence of dysfunctional interactions between neural and immune signals that result in increased peripheral immune responses and increase proinflammatory cytokines. In the last section, we discuss autism spectrum disorders and altered brain circuitries that emerge from abnormal long-term responses of innate inflammatory cytokines and microglial phenotypic dysfunctions.

(c) 2018 S. Karger AG, Basel

Ana Clara Liberman

Instituto de Investigación en Biomedicina de Buenos Aires (IBioBA) -

Instituto Partner de la Sociedad Max Planck

Godoy Cruz 2390, C1425FQD Buenos Aires (Argentina)

E-Mail aliberman@ibioba-mpsp-conicet.gov.ar

Claudio A. Serfaty

Instituto de Biologia, Universidade Federal Fluminense

Outeiro de São João Batista, s/n CEP: 24020-141 Niterói (Brazil)

E-Mail cserfaty@id.uff.br 


\section{Introduction: Cellular and Molecular Basis of Neuroinflammation in the Brain}

Disturbances of the central nervous system (CNS) homeostasis (e.g., infection, trauma, ischemia, neurodegenerative diseases, and neurodevelopmental and psychiatric disorders), evoke neuroinflammatory responses in the brain. Microglial cells are designed to interpose the insult effect with the secondary activation of astrocytes that can modulate the recruitment and activation of other immunocompetent cells to the injury site. However, a persistent activation, associated with an increase of inflammatory cytokines and chemokines, followed by the recruitment of peripheral phagocytes can be deleterious to neurons and brain function [1-5].

Based on the activation stimuli and (micro)environmental factors, surveying microglia (M0) may change into two phenotypes: the proinflammatory "M1" phenotype, activated by lipopolysaccharides (LPS) and interferon- $\gamma$, corresponding to the "classical" pathway of macrophage activation; and the anti-inflammatory "M2" phenotype, activated by interleukin (IL)- 4 and IL- 13 through the "alternative" pathway of macrophage activation $[6,7]$. Thus, the microglial population responds with a rapid morphological shift from a surveilling, ramified phenotype, to an amoeboid phenotype associated with changes in gene expression, ultimately leading to an activation state [8]. In a resting state, microglia are constantly scanning the neuropil through their highly motile processes acting on synapse maintenance, neurogenesis and growth factors secretion to keep CNS homeostasis. Under insult signals, microglia is converted into an activated mode. A short or moderate signal directs microglia toward a neuroprotective, M2 phenotype, whereas an intensive acute or chronic activation renders an M1 microglia phenotype which is potentially neurotoxic. Under such conditions, microglia fail to acquire a neuroprotective phenotype, producing reactive oxygen species, nitric oxide, proteases, and proinflammatory cytokines such as IL-1 $\beta$, IL-6, and tumor necrosis factor- $\alpha$ (TNF- $\alpha$ ), all of which, may endanger neuronal population. Under severe conditions, however, M1 microglia may also recruit monocyte-derived macrophages that secrete anti-inflammatory cytokines such as IL-10 and TGF- $\beta$ to restore neuroprotection and cell renewal [9]. Also, under mild microglial activation, TNF- $\alpha$ can stimulate the release of trophic factors related to neuroplasticity and repair [10] and increase the production of glial cell line-derived neurotrophic factor (GDNF) and nerve growth factor (NGF) by astrocytes [11]. In this way, microglial cells express a range of func-

Neuroimmune and Inflammatory Signals in Complex Disorders of the CNS tional states with dynamically pleomorphic profiles [12]. Therefore, a microglial to monocyte-derived macrophage cross talk seems to be instrumental under severe lesion conditions [9]. Microglia also activates astrocytes that can modulate the recruitment and activation of additional microglial and other immunocompetent cells to the injury site closing the circle of a reactive positive feedback $[13,14]$. Microglial cells express a variety of receptors for a plethora of molecules that allow them to sense environmental changes over a time scale of minutes and respond in a way that might lead to either beneficial or harmful results, according to the context $[15,16]$. Two major signaling cascades, the $\mathrm{Ca}^{2+} /$ calcineurin/NFAT and $\mathrm{NF \kappa B}$ pathways seem to be involved in microglial activation. Once in the nucleus, NFAT and NFKB interact with distinct DNA-binding elements to drive the expression of multiple cytokines $[17,18]$.

Several studies have shown the bidirectional interplay between the immune system activation and neuronal function. Whole-cell patch clamp experiments revealed that activation of dendritic glutamate NMDA receptors on single neurons was sufficient to trigger microglia process outgrowth [19], thereby demonstrating a direct link between neuronal activity and the dynamics of microglia dendritic-like processes. In the zebrafish larvae, neuronal activity was reduced by microglia contact while, conversely, preventing microglial processes from spontaneously contacting active neurons significantly enhanced neuronal activity, suggesting that neuronal activity itself can be altered by microglial interaction [20]. Also, microglial activation is associated with altered long-term potentiation (LTP) [21], the synaptic correlate of memory. Furthermore, calcineurin, a $\mathrm{Ca}^{2+} /$ calmodulin-dependent phosphatase, not only induces microglia reactivity but modulates synaptic activity through dephosphorylation of several targets required for LTP/LTD, including the modulation of NMDA receptor activity [22] and the suppression of glutamate release [23]. Microglia also responds to high concentrations of extracellular ATP through P2X7 receptors (P2X7R) [24]. Neuroinflammation and abnormal microglial activation may also play a mechanistic role in synaptopathies affecting cognition and function [25-27].

An extensive microglial-astrocyte-monocyte-neuronal cross talk seems to be crucial not only for normal brain development and function but also for the injured, severely dysfunctional, brain.

Surprisingly, in recent years, cumulative evidence has demonstrated the relevance of inflammatory mediators, immune cells, and related molecules in the development 
of CNS pathologies of very diverse origin and etiologies. With the aim of highlighting differences and commonalities, we will analyze the involvement of neuroimmune interactions in four different pathologies: (a) the injured brain and its associated plasticity adaptations, (b) the brain of amyotrophic lateral sclerosis (ALS) patients as an example of neurodegenerative diseases, (c) major depression disorder (MDD), an emotional alteration of a still unknown though probably multifactorial mechanistic bases, and (d) autistic spectrum disorders (ASD) as an example of neurodevelopmental disorders.

\section{Inflammation and Lesion-Induced Plasticity in the CNS}

Brain plasticity in response to lesions is rapid and usually leads to functional recovery in the neonatal brain. However, in adults, various forms of lesions usually result in a lower recovery ratio. Inflammatory mechanisms have been involved in the modulation of reactive plasticity of intact neuronal populations in various forms of brain injury, as well as the involvement of microglial and astrocytic activation in recovery and repair of neural circuits. Then, why is the CNS so plastic during early development? Why does plasticity decrease in adulthood? Does the rapid plasticity found in infants relate to the profile and time course of glial activation? Strategies seeking the modulation of the different profiles of reactive microglia and astrocytes during early brain development may emerge as potential mechanisms to allow a more permissive milieu to plasticity and recovery in the adult brain.

\section{Critical Periods of Development and Lesion-Induced}

\section{Plasticity in the CNS}

The use-dependent development of functionally organized connections in the mammalian CNS occurs over a time window known as the critical period [28]. The critical period represents a stage of development where environmental signals promote fast use-dependent rearrangements of neuronal networks, required for the acquisition of proper sensory, motor, and cognitive skills [29]. The closure of critical period affects the plasticity of the primary sensory areas of the brain, slowing down usedependent changes of sensory-motor, as well as cognitive systems [28, 29]. However, as the critical period closes, plasticity continues, albeit at a lower speed, for both cortical and subcortical structures [30, 31]. In adults, neocortical plasticity can be reactivated by modifications of sensory inputs or sensory-motor interactions, which alter the overall level of activity in cortical circuits [29]. Therefore, brain plasticity is not uniform throughout life: plastic recovery after a brain lesion usually peaks in infancy and declines over the years [28].

\section{Lesion-Induced Plasticity and Models}

During the critical period, lesions such as contralateral eye monocular enucleation or restricted lesion to the contralateral retina trigger a series of adaptive responses of the visual system $[31,32]$. In rodents, monocular enucleation leads to a massive deafferentation of subcortical visual targets of retinal axons, the dorsal lateral geniculate nucleus and superior colliculus, resulting in a remarkable plastic response of intact axons originating in the remaining eye with extensive sprouting over denervated territories [33] (Fig. 1). The plasticity of intact pathways is an important model for other forms of CNS trauma, such as traumatic brain injury, spinal cord lesions, and stroke. The functional recovery expected in those conditions relies on strategies minimizing neuronal lesion and optimizing neuronal plasticity, most of it on the regrowth of intact axonal pathways $[34,35]$. Thus, uncovering the cellular and biochemical mechanisms related to plastic remodeling after CNS injury during early development might be a necessary step to improve functional recovery after brain lesions in adult individuals.

\section{Role for Glial Cells in CNS Injury}

Lesions triggered by trauma, ischemia, or infections can induce a heterogeneous and stimulus-dependent glial response known as reactive gliosis. The cross talk between microglia and astrocytes in the context of CNS injury is critical to determine intensity and time length of such glial response. During reactive gliosis, these cell types present distinct temporal activation patterns, so that while microglia is the first cell population to detect and respond to CNS homeostatic disturbances by secreting inflammatory cytokines and chemokines, astrocytes are sequentially activated by these signals [14]. On the other hand, once activated, astrocytes can modulate the recruitment and activation of microglial and other immunocompetent cells to the injury site and, later on, form a glial scar which encapsulates the lesion core from the healthy CNS areas [13].

Following a monocular enucleation in rodents, microglia activation occurs quickly after denervation and precedes astrogliosis mainly in contra- but also in ipsilateral subcortical structures, including the lateral geniculate nucleus and superior colliculus $[36,37]$. Both microglial cells and astrocytes are known to clean up axonal de- 


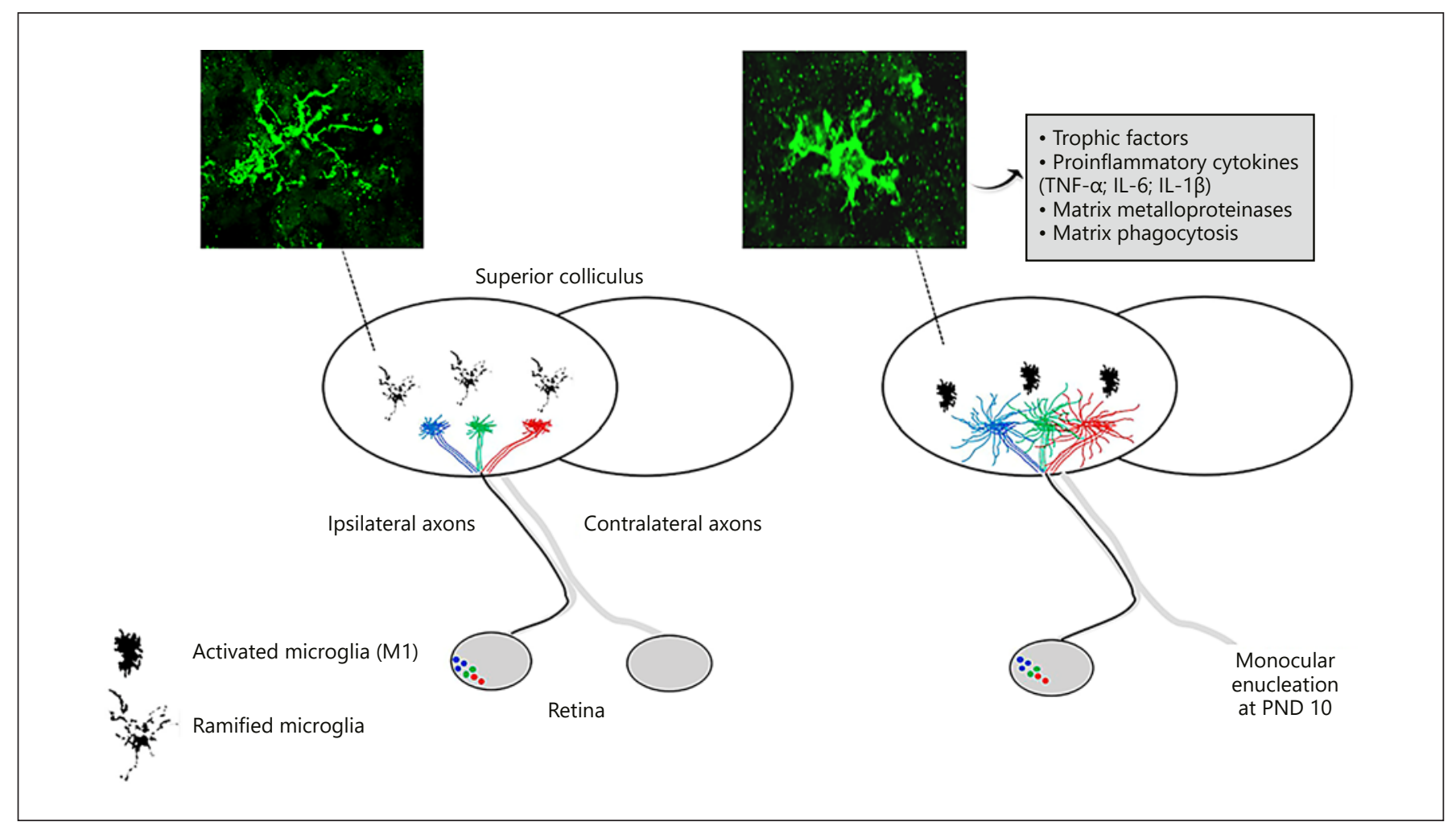

Fig. 1. Microglial activation and plasticity of the ipsilateral retinocollicular projection in a monocular enucleation model. During early postnatal development, the intact rat visual system displays a population of ramified M0 microglial cells at the time of circuitry refinement (left panel). Microglial activation is induced by a monocular enucleation at postnatal day 10 (PND10). The appearance

bris, restore tissue homeostasis and release growth factors and cytokines to stimulate neuronal sprouting [38]. Although, many studies have focused on a role of microglial cells in the mechanisms associated with a normal developmental plasticity, such as synaptic pruning [39, 40], little is still known on the influence of activated cells and the critical mechanisms mediating a reactive plasticity of nonlesioned neurons and its axonal pathways.

\section{Microglia and Lesion-Induced Plasticity}

A role for microglial cells in axonal sprouting following CNS lesions was suggested by Ngu et al. [41], in a study where they provided evidence that a full accumulation of microglia is necessary for the usual sprouting and regeneration of severed axons in the leech CNS. In the mammalian visual system, we are currently demonstrating that microglial activation plays a role in the reactive sprouting of intact axons of the retinocollicular pathway in response to a lesion in the contralateral eye. Our cur- of an M1-like phenotypic profile is co-temporal with a rapid growth of intact retinal axons from the remaining eye (right panel) [Chagas et al., manuscript in preparation]. Activated microglia seems to be necessary for neuroplastic adaptation of axons from the intact eye. Retinogeniculate projections are not displayed. Eye opening at PND14. rent data suggest that, during early postnatal development, there is a strong temporal correlation between axonal plasticity and microglial activation $24 \mathrm{~h}$ after a monocular enucleation in rats [Chagas et al., manuscript in preparation] (Fig. 1). Moreover, we prevented an axonal reactive sprouting with an acute systemic administration of different microglial inhibitors, cyclosporine $\mathrm{A}$ and minocycline. Accordingly, Bechmann and Nitsch [38] also correlate microglial activation with circuit reorganization in the hippocampus following a lesion to the entorhinal cortex. Sprouting and synaptogenesis of denervated dendrites were observed in hippocampal terminals, in such a way that both degeneration and reorganization were initially accompanied by alterations in morphology and microglial function, followed by astrocytic modifications.

Several studies correlate the role of microglia in injuryinduced plasticity with the release of trophic factors. In an experimental model of acute corticospinal tract injury, immunosuppressed animals did not present a plastic re- 
sponse as effective as immunocompetent animals, whose axonal growth was associated with neurotrophin-3 overexpression [42]. Similarly, Batchelor et al. [43] showed that neuronal sprouting of serotonergic and dopaminergic fibers coincides with the presence of activated microglia expressing mRNA for brain-derived neurotrophic factor (BDNF) and GDNF. In accordance, it has been demonstrated that microglia is capable of secreting trophic factors involved in neuritogenesis and, in activated state, seems to support axonal sprouting via insulin-like growth factor 1 [44].

Several lines of evidence have been ascribing a role for proinflammatory cytokines in lesion-induced plasticity. Acute lesions in the CNS promote the release of a variety of proinflammatory cytokines by microglia and astrocytes, like TNF- $\alpha$, IL-1 $\beta$, and IL-6. In traumatic brain injury models, some studies point to TNF- $\alpha$ as an important factor in its pathophysiology, while other studies demonstrate a neuroprotective role in this same model of injury [45]. TNF- $\alpha$ can assume opposing roles that may vary according to the region of the brain and the context of the lesion or disease, among other factors. Oshima et al. [46] observed that TNF- $\alpha$ contributes to axonal sprouting and functional recovery after traumatic brain injury, since in TNF- $\alpha$ KO animals, no regeneration in the corticospinal tract could be observed. Moreover, Kreutz et al. [47] used TNF- $a$ neutralizing antibody to abolish axonal regrowth after optic nerve crush experiments. In addition to this, TNF- $\alpha$ also stimulates the release of trophic factors associated with neuroplasticity by microglia [10] and upregulates the levels of GDNF and BDNF factors in astrocyte primary cultures [11]. Indeed neurotrophic factors play a role in both normal and abnormal conditions as it has been shown that an impoverished environment delays maturation of the visual cortex [48]. On the other hand, an environmental enrichment promotes visual acuity recovery in amblyopic adult mice, and both phenomena are related to BDNF and GABAergic function [49]. Furthermore, it has been shown that either microglial depletion or a Cre-dependent removal of BDNF from microglia resulted in deficits in multiple learning tasks and a significant reduction in motorlearning-dependent synapse formation [50].

In a model of Schaffer collateral transection in organotypic hippocampal slice cultures, IL-6 induced sprouting and promoted synaptic response recovery [51]. Also, adrenergic sprouting was attenuated in IL-6 KO mice in a model of spinal nerve lesion [52]. In the monocular enucleation model, Vasques et al. [32], brought evidence that $\alpha$-secretase activity is important for the axonal sprouting of ipsilateral retinocollicular projections from the intact eye, by favoring the production of sAPPa. Furthermore, it has been described that the proinflammatory cytokine IL- $1 \beta$ enhances $\alpha$-cleavage of APP, upregulating sAPP $\alpha$ content in vitro [53]. Therefore, it seems that inflammation modulates extracellular proteolytic activity that in turn regulates plasticity. Indeed, it has been shown that axonal sprouting in response to a lesion in the visual system depends on the activity of MMP-9 [54].

The M1 microglia phenotype has a central role in host defense against pathogens and tumor cells but also triggers damage to healthy neurons [55]. Despite that, in the range of molecules produced and secreted by M1-type microglia, we find the necessary machinery to support the mechanisms by which activated cells can mediate lesioninduced plasticity of intact circuitry, described above. These cells produce TNF- $\alpha$, IL- $1 \beta$, IL- 6 , proinflammatory cytokines that act on the regulation of specific axonal reorganization as growth factors. In parallel, the M1 type not only produces matrix metalloproteinases but also phagocyte axonal debris and extracellular matrix that can act as barriers for the sprouting fibers in the CNS $[6,38]$.

\section{Reactive Astrocytes and Lesion-Induced Plasticity}

A hallmark of astrocyte activation is the upregulation of the intermediate filaments glial fibrillary acid protein (GFAP) and vimentin, and the early activation of the transcription factor STAT3. Mice deficient for these filaments $\left(\mathrm{GFAP}^{-} / \mathrm{Vim}^{-}\right)$or under conditional deletion of STAT3 from astrocytes (STAT3-CKO) present reduced reactive gliosis and glial scar formation induced by lesions. Experiments using STAT3-CKO mice have shown pronounced functional impairment after spinal cord injury, accompanied by an increased number of reactive microglia at the lesion core and a general spread of inflammation [56, 57]. Therefore, activation of astrocytes seems to be important to gradually suppress microglia and other inflammatory players by constraining the lesion size [58]. However, a persistent astrocyte activation followed by glial scarring is consistently associated with inhibition of structural plasticity $[59,60]$. Reactive astrocytes overexpress molecules like chondroitin sulfate and ephrin-A5 which block axon regeneration and outgrowth, respectively $[61,62]$. In fact, $\mathrm{GFAP}^{-} / \mathrm{Vim}^{-}$mice exhibit improved axon regeneration after optic nerve crush [63] and functional recovery after spinal cord trauma [64]. Thus, in a broad perspective, reactive astrocytes may play a beneficial role in the acute phase of trauma by modulating the inflammatory response. A long-term astrocytic activation, however, restricts the regenerative potential by secreting inhibitory molecules. 
It has been shown that reactive astrocytes can exhibit different phenotypes depending on the nature of injury. A comparison between ischemic stroke and LPS-dependent inflammation models in mice has shown that the gene expression pattern in reactive astrocytes was stimuli-specific [65]. Based on those findings, it was recently proposed that reactive astrocytes can be classified as A1 astrocytes, which secrete proinflammatory signals that are harmful to neurons, or A2 astrocytes, which, in turn, secrete neurotrophic factors that can promote survival and modulate inflammatory response. In fact, A1 astrocytes were induced in vivo by LPS-dependent microglia activation [66]. This activation profile leads these cells to secrete toxic factors as well as losing major trophic functions like synapse support and phagocytic capacity. Interestingly, $\mathrm{A} 1$ astrocytes seem to be specifically induced by three simultaneous microglia-derived signals: TNF- $\alpha$, IL$1 \alpha$, and $\mathrm{C} 1 \mathrm{q}[66]$. Thus, a possibility arises that different pools of cytokines secreted from activated microglia can potentially drive distinct astroglial responses, which in turn can affect the extension and phenotype of the lesion and also of the glial scar.

Data from the literature have evidenced the role for reactive astrocytes in facilitating synaptogenesis and neurite outgrowth in a lesion environment through the release of trophic factors [67]. However, once activated, astrocytes form a glial scar which encapsulates the lesion core from the healthy CNS areas [13]. The chondroitin sulfate proteoglycan NG2, a component of the glial scar was correlated with the postlesional sprouting response in the rat fascia dentata following unilateral entorhinal deafferentation that could define boundaries for growing axons [68]. Furthermore, ablation of scar-forming astrocytes in a forebrain stab injury model resulted in increased local neurite outgrowth, revealing their role in restricting nerve fiber growth after injury [69].

Strategies seeking the modulation of the different profiles of reactive microglia and astrocytes during reactive gliosis may emerge as a potential alternative to allow a more permissive milieu to plasticity events in adulthood. The correct timing of glial activation and molecular signaling pathways must be considered as targets for CNS plasticity and repair.

\section{Neuroinflammation in Neurodegenerative Diseases}

The current increase in life expectancy results in an increase in neurodegenerative diseases including Alzheimer's disease, Parkinson's disease, ALS, and Hunting-

Neuroimmune and Inflammatory Signals in Complex Disorders of the CNS ton's disease, among others. Neurodegeneration is associated with age with an estimated prevalence oscillating between 1.5 and $2.5 \%$ of the general population but rises to $50 \%$ in people with more than 85 years [70-72]. It is well accepted that the pathogenesis of neurodegenerative diseases is associated with an underlying inflammatory process in the affected areas of the CNS, which is known as "neuroinflammation" $[73,74]$. Primary neuron damage likely triggers local neuroinflammation through the release of trophic factors and inflammatory mediators [75]. Damage neurons express a large variety of inflammatory mediators such as CSF1, TGF- $\beta$, IFN $\gamma$, and Fas/ FasL, with the potential to elicit a localized inflammatory response [76-80]. Innate and adaptive immune responses underlie neuroinflammation, involving the complex participation of microglia, as the resident immune cell of the CNS as well as astrocytes and oligodendrocytes, which actively interact with other immune cells including $\mathrm{T}$ cells, monocytes, and mast cells [81-86].

When regulated and properly resolved, neuroinflammatory mechanisms can be considered as a regenerative response against damage, with glial and immune cells playing a critical adaptive role in maintaining tissue homeostasis [87]. However, if neuroinflammation is not adequately shut down, its chronic, unregulated activation becomes deleterious having the potential to be neurotoxic, compromising neuronal and progenitor survival. In addition, the blood brain barrier (BBB) and the blood spinal cord barrier make the CNS an immunologically privileged area, with limited capacity to recruit immune cells from the circulation [4, 88]. Moreover, the CNS displays a low immune surveillance and absence of specialized antigen-presenting cells, which further limit the local immune responses. Despite this immunologically privileged status, Tlymphocytes and monocytes can be trafficked into the CNS parenchyma to instrument specific inflammatory responses in regions of the CNS undergoing tissue damage (Fig. 2) [89-92].

\section{Pathogenic Role of Glial Cells in ALS}

Histopathological, immunological, and biochemical evidence indicates that neuroinflammation greatly influences the progression of neurodegenerative diseases. Among them, ALS is a paradigmatic disease where inflammation develops along the motor pathway, into both the CNS and the peripheral nervous system (PNS) [81, 93, 94]. Moreover, therapeutic compounds targeting inflammation are currently being tested in a clinical trial with the aim to reduce the upper and lower motor neuron degeneration in ALS, thus delaying progressive muscle weakness [95-97]. 


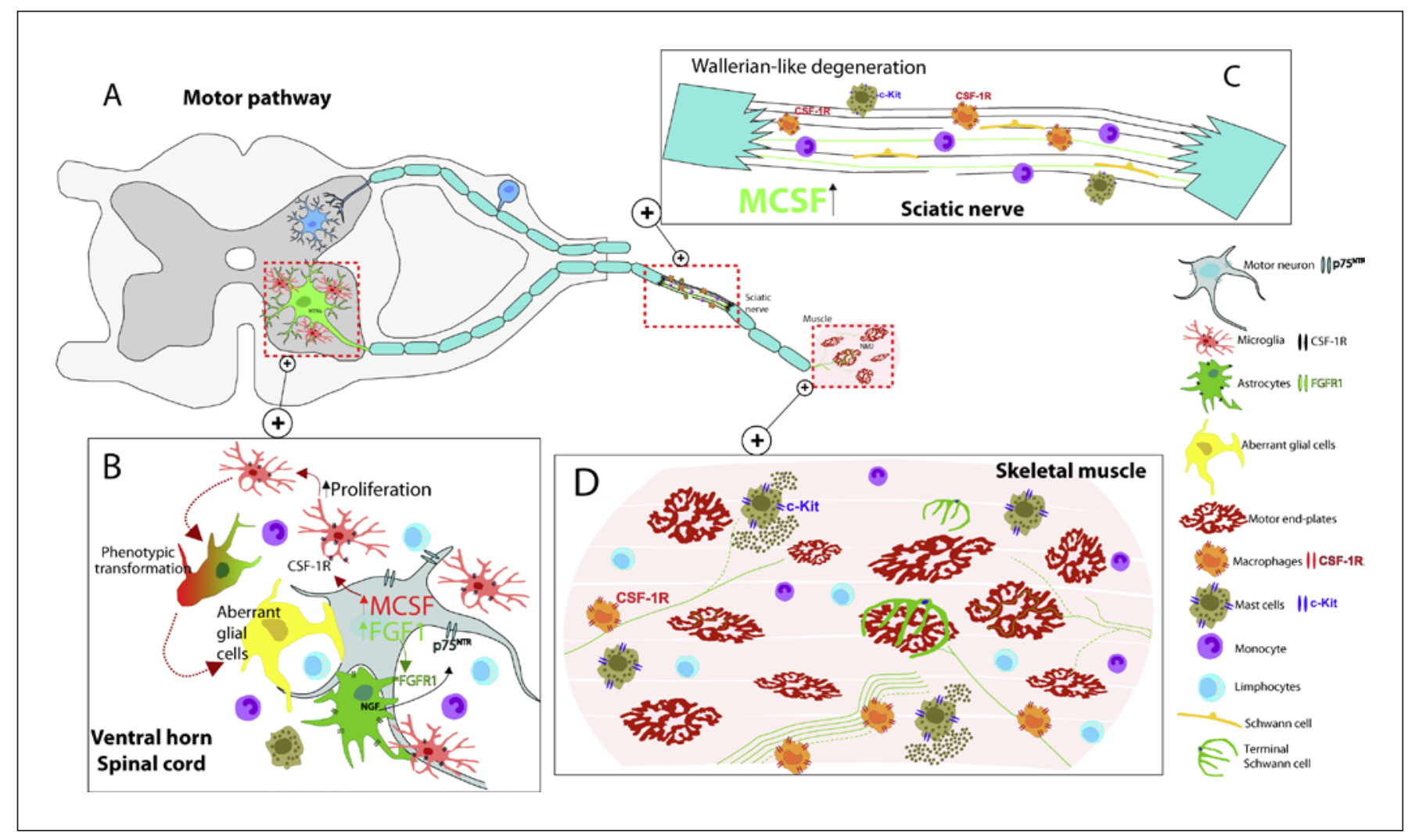

Fig. 2. Neuroinflammatory mechanisms influencing lower motor neuron degeneration in ALS. A, B Representative drawing showing how neuroinflammation orchestrates a neurodegenerative microenvironment along the motor pathway during disease progression in ALS. In the ventral spinal cord, glial cells, astrocytes, and microglia proliferate and surround degenerating motor neurons after disease onset. Such neuroinflammatory scenario promotes the emergence of a subpopulation of aberrant glial cells that actively proliferate and likely are highly toxic to motor neurons. The constitution of this neurodegenerative microenvironment contributes to the acceleration of paralysis progression. Dying motor neurons can release several factors that stimulate glial cell proliferation and activation, including FGF-1 and MCSF. FGF-1 stimulates surrounding astrocytes to express and release NGF which in turn can induce motor neuron death through $\mathrm{p} 75^{\mathrm{NTR}}$. MCSF is an agonist of CSF-1R, thus stimulating microglia proliferation and activation. Other immune cells such as monocytes, mast cells, and lympho-

Astrocytes contribute to orchestrate chronic neuroinflammation in ALS, displaying a variety of phenotypic changes, with the potential to induce motor neuron apoptosis $[66,82,98,99]$. Astrocytes are in direct contact with neurons, providing structural, metabolic, and trophic support, while actively participating in the modulation of neuronal excitability and neurotransmission [100]. However, in pathological conditions astrocytes become hyper- cytes infiltrate the spinal cord of ALS during the symptomatic phase of the disease. C, D The degeneration of peripheral motor axons in ALS also triggers a potent inflammatory response, both in peripheral motor axons and in skeletal muscles. Motor axon degeneration is characterized by Schwann cell proliferation and immune cell infiltration such as macrophages, monocytes, lymphocytes, and mast cells. C Degenerating motor axons can express and release MCSF, which induces macrophage infiltration through CSF-1R activation. Neuromuscular junction (NMJ) denervation constitutes one of the first pathological events of ALS, taking place even before spinal cord and peripheral nerves become compromised and symptoms appear. NMJ denervation and terminal Schwann cell dissociation from the motor end-plates is accompanied by significant mast cell infiltration and degranulation after disease onset. Macrophages also infiltrate skeletal muscle during disease progression. 
tory phenotype in surrounding astrocytes $[105,106]$. For example, FGF-1 is strongly upregulated in motor neurons after sublethal damage and, once released, induces the activation of astrocyte through activation of its cognate receptor FGF-1R [105]. FGF-1R activation in astrocytes strongly induces transcription factor nuclear factor erythroid 2-related factor-2 (Nrf2), which likely mediates cytoprotective effects $[107,108]$. In addition, FGF-1 strongly induces nerve NGF expression in astrocytes, which upon secretion can activate the proapoptotic neurotrophin receptor $\mathrm{p} 75^{\mathrm{NTR}}$ [109]. Because postnatal motor neurons can express p75NTR following nerve injury or during neurodegeneration [110-112], the NGF/p75NTR pathway might modulate the elimination of neurons in ALS. Such NGF-mediated motor neuron apoptosis is further stimulated by nitric oxide and peroxynitrite, a mechanism linking oxidative stress and mitochondria failure in astrocytes to motor neuron cell death [98]. The finding that astrocytes from ALS patients and animal models are neurotoxic to motor neurons, suggests a pathogenic pathway based on a defective function of glial cells that surround the motor neuron cell bodies, implying loss- and gain-of-function mechanisms associated with inflammation [113-115].

Activated microglia also drive neuroinflammation in ALS, being a fundamental part of the innate immune response in the CNS [116]. Pathological microglia can present diverse states of activation depending on the induction trigger by the microenvironment $[117,118]$. During the symptomatic phase of ALS, microglia are characterized by proliferation and transformation into phagocytic cells, displaying a morphology similar to that of macrophages in the periphery $[118,119]$. They can form clusters of proliferating microglia adjacent to the damaged motor neurons $[120,121]$, thus playing a preponderant pathogenic role during the progression of ALS $[122,123]$. In a mouse model of ALS expressing mutant SOD1, genetic excision of the mutated protein only in myeloid cells and microglia results in a slower paralysis progression as compared with mice expressing the mutant protein in microglia [124]. Microglia from mice expressing ALSlinked SOD1 mutations cause neurotoxicity to motor neurons in culture conditions [122, 125]. These results suggest activated microglia actively contribute to motor neuron damage through the induction of local detrimental inflammation.

Relevant for the understanding of the pathogenic role of microglia in ALS is the fact that following activation, microglia display different phenotypes depending on the induction exerted by the microenvironment $[117,118]$. While

Neuroimmune and Inflammatory Signals in Complex Disorders of the CNS some phenotypes can be deleterious for neuronal survival, other coexisting phenotypes can be neuroprotective. Therefore, pharmacological targeting of microglia could only have beneficial effects if restricted to those pathological phenotypes. For example, in ALS mouse models, the drug minocycline is able to inhibit microgliosis and decrease inflammation in the CNS, delaying paralysis onset and progression of symptoms [126]. However, minocycline failed to improve survival when tested in ALS patients [127].

In ALS paralytic rats expressing the $\mathrm{SOD} 1^{\mathrm{G} 93 \mathrm{~A}}$ mutation, overactivated microglia in the spinal cord originate an aberrant cell phenotype displaying both microglia and astrocyte markers in the ventral horn of the spinal cord $[120,128]$. Moreover, such aberrant glial cells actively proliferate after the onset of paralysis and make intimate contact with degenerating motor neurons, suggesting they contribute to spread motor neuron pathology [120, 128]. Accordingly, aberrant glial cells isolated in culture are highly toxic to motor neurons, suggesting they are key neurotoxic effectors in ALS [128]. Based upon these observations, Trias et al. [129] investigated whether ALS progression might be ameliorated by masitinib, a drug that potently targets aberrant glial cells through the inhibition of the tyrosine kinase receptor CSF-1R. ALS rats treated with masitinib after paralysis onset displayed decreased inflammation in the CNS and PNS [129], and in parallel the treatment prevented motor neuron loss and denervation of neuromuscular junctions $[81,129]$.

\section{Inflammation along the Peripheral Motor Pathway in ALS}

Neuroinflammation in ALS also involves the participation of blood-borne immune cells such as lymphocytes, monocytes, mast cells, and neutrophils, among others $[92,130-132]$. These cells are known to permeate the BBB in specific regions and actively interact with the degenerative cellular microenvironment surrounding motor neurons and motor axons $[81,131,133,134]$. It is also possible that chronic neuroinflammation restricted to the CNS can extend to skeletal muscles and then to other organs, becoming a systemic inflammation $[135,136]$. Evidence indicates that these cells can exert both neuroprotective and neurotoxic influence on motor pathways [137]. Thus, proinflammatory Ly6C ${ }^{\text {hi }} \mathrm{CCR} 2+$ monocytes from the blood have been shown to infiltrate mice spinal cord, contributing to the death of the motor neurons. The genetic attenuation of these neurotoxic monocytes is sufficient to significantly slow the course of the disease [130].

Along this line, ALS patients display higher levels of circulating monocytes, neutrophils, and CD4 lympho- 
cytes, with the increased number positively correlating with a more rapid progression of the disease $[132,138]$. Mouse models as well as ALS patients also have high levels of cytotoxic CD8 lymphocytes and circulating natural killer cells $[133,139,140]$. Patients also show dysfunctional regulatory $\mathrm{T}$ cells (Treg), which correlate with the progression and severity of symptoms [135, 141, 142]. This finding is currently under evaluation as a potential therapeutic strategy in ALS [135]. Finally, it has been shown that mast cells can infiltrate the spinal cord of patients with ALS during the symptomatic phase of the disease, and through dialogue with the microglia, they could contribute to the degeneration of motor neurons [131, 133].

Using a transgenic rat model of ALS, Trias et al. [81] reported histopathological evidence for mast cells favoring neuromuscular junctions (NMJs) pathology and paralysis progression in ALS, representing a previously unknown and significant inflammatory pathogenic mechanism. Interestingly, massive mast cell infiltration into skeletal muscle correlates with paralysis progression, with a clustering of inflammatory cells around denervated NMJs. Downregulation of infiltrating mast cells by therapeutic doses of the tyrosine kinase inhibitor drug masitinib that inhibit the c-Kit receptor resulted in a significant delay of muscle denervation [81]. This study further supports a role of inflammation in the PNS. The deeper understanding of the inflammatory mechanisms that underlie this fulminant neurodegenerative disease, will allow a more specific search for novel therapeutic strategies that seek to slow its progression.

\section{Neuroimmune Basis of the Mechanisms of Depression}

\section{Depression, an Epidemiological Burden with Elusive Causal Mechanisms}

MDD is a main contributor to the global burden of disease with a lifetime prevalence of 14.6 and $11 \%$ in highincome and low/middle-income countries, respectively [143]. Along this line, MDD and anxiety are the leading cause of years lived with disability [144], and approximately $30-50 \%$ of these patients are not responsive to standard antidepressant medication [145, 146]. Despite the cost for the national systems of health, the epidemiological relevance, and the billionaire investments in R\&D both in the academy and industry, the underlying basis of MDD remains unknown. Although genetic signatures impose some heritable risk for developing depressive symptoms, it seems so far evident that depression is a rather syndromic, multifactorial disorder that involves the interplay of genetic predispositions and environmental factors out of which maladaptive responses to traumatic or psychosocial chronic-stress arguably are amongst the most frequent [147-150]. Over the past 35 years, numerous studies revealed the existence of a complex but robust bidirectional communication between immune, endocrine, and neural systems [151-157]. In this context, a multiplicity of studies have been reported suggesting a role of immune and inflammatory signals in MDD [158160].

\section{MDD: The Consequence of a Dysfunctional}

Interaction between Neural and Immune Signals?

One of the most indicative clinical suggestions of the association of inflammation and MDD is the elevated prevalence of depression comorbidity with inflammatory-related diseases such as diabetes, metabolic syndrome, asthma, multiple sclerosis, and rheumatoid arthritis [159, 161]. More specifically, a series of clinical correlative studies carried out by Maes et al. [162-164] in the early 1990s revealed the association between depressive symptoms and increased peripheral immune responses and inflammatory biomarkers including acute-phase proteins as well as inflammatory cells and cytokines. In the following years, these results have been vastly replicated and extended [159], and further meta-analyses have shown that while natural killer and T-activity are moderately reduced, several hallmarks of inflammation such as IL-6, TNF- $\alpha$, IL- $1 \beta$, and the acute-phase C-reactive protein (CRP) are the markers most reliably associated with depression [165-167].

Recently, a study conducted by Felger et al. [79] using resting-state functional magnetic resonance imaging in MDD unmedicated patients, showed a negative association between blood levels of CRP and inflammatory markers (IL-1 $\beta$, IL-6, and IL-1RA) and connectivity of reward-related brain circuits such as ventral striatum and ventromedial prefrontal cortex. These findings suggest that inflammatory mediators might directly target reward circuits in depression.

Interestingly, the link between inflammation and depressive symptoms might also have predictive value since patients with lower baseline inflammatory markers are more likely to respond to antidepressant treatment [168170]. Other studies however, reported no changes in the plasma levels of IL-1 $\beta$, IL-6, and transferrin receptor in fluoxetine-treated patients $[171,172]$. These contradictory findings may be attributable to differences in age, 
gender, and treatment duration but could also be indicative that the influence of inflammation in MDD occurs only in a subset of so far poorly defined patients. In any case, when analyzing association studies in humans, it is always relevant to underline that correlative phenomena do not imply causation but co-occurrence. Even though many studies on animal models suggest a causal relationship between immune-related molecules and depressivelike behaviors, this causality has not been proven beyond doubt in humans yet. Future studies in preclinical animal models and humans will help understand whether depression and chronic inflammatory diseases are mechanistically linked or if chronic peripheral inflammation influences the course of MDD via independent mechanistically unrelated events.

\section{Peripheral Immune Cells and Cytokines in Chronic Stress and Depression}

Both environmental and systemic stress rapidly activates hypothalamic pituitary adrenal axis (HPA) and the efferent autonomic pathways [173-175]. Noradrenaline is directly released on peripheral organs by sympathetic terminals and the endocrine release of adrenaline increases heart rate and blood pressure and favors glucose availability. At the immunological level, these catecholamine mediators lead to the expansion and mobilization of hematopoietic phagocytes in the bone marrow [176, 177]. In parallel, the synthesis and release of glucocorticoid (GC) by the adrenal cortex first promote immune cell mobilization to injured tissues and primes immune cells for subsequent inflammatory challenges [107, 178, 179]. Later on, if the stress challenge persists, the sustained elevation of GC homeostatically suppresses inflammation and acquired immunity, thus preventing overactivity of innate inflammatory responses and preserving the specificity of immune reactions [180-182]. In his original description, Tausk [183] actually assigned to GC a broad shutdown function in the general stress response and exemplified stress to a fire and the role of GC to that of preventing water damage caused by the firefighters.

At the central level, chronic or repetitive stress induces a desensitization of corticosteroid receptor-mediated feedback mechanisms that result in high and-long lasting production of corticotropin-releasing factor and vasopressin, and this dysregulation sustains a higher basal activation of the HPA axis and favors stress vulnerability to new traumatic episodes [147, 184-187]. The GC receptor (GR) desensitization seems to be pleiotropic and takes place in peripheral immune cells too. Multiple and even-

Neuroimmune and Inflammatory Signals in Complex Disorders of the CNS tually coincident mechanisms such as epigenetics marks, increased expression of GR $\beta$ isoforms, microRNA-mediated instability, or posttranslational modifications might help explain the long-lasting changes in GR feedback sensitivity [188-190]. Recent findings suggest that epigenetics mechanisms might be particularly relevant to understand the dysregulation of stress-related pathways.

In rats, low levels of maternal care induce a long-lasting decrease in central GR transcription, a phenomenon mediated by increased levels of histone 3 lysine 9 acetylation (H3K9) and decreased DNA methylation of exon I7 of the GR promoter [191]. Interestingly, similar epigenetics marks have been found in the human orthologous site of the GR promoter (GR 1F) in the hippocampus of suicide victims with early exposition to child abuse [192]. These environmental effects on the epigenetic regulation of gene expression might be influenced by genetic variation giving rise to the concept of gene $\times$ environment interaction. Klengel et al. [193] showed for the first time a significant gene $x$ early trauma interaction based on the epigenetic regulation of an MDD-associated polymorphism of FKBP5, a GR-induced co-chaperone that restricts GR transactivation in an ultrashort feedback $[194,195]$. Risk-allele carriers show an increased GR-mediated induction of FKBP5 which would lead to GR resistance and HPA hyperactivation. Prolonged high-cortisol levels and GR activation as a result of chronic abuse or maltreatment during childhood induces a long-lasting demethylation of GC response elements and further transcriptional depression of FKBP5 [18] perpetuating the GR resistance and stress dysregulation specially in risk allele carriers with a history of childhood trauma. The dysregulation of the negative feedback mechanism favors an increase in the basal proinflammatory status, which additionally contributes with the GR resistance (Fig. 3). Mechanistically, cytokine-induced repression of GR might be mediated by the activation of NF- $\mathrm{KB}$ and AP-1 transcription factors that reduce GR transactivation either by inhibiting GR nuclear translocation or by blocking accessibility to chromatin remodelers or transcriptional cofactors [157, 196-199]. Along this line, chronic stress or prolonged exposure to GCs in rodents reduces the sensitivity of immune cells to the anti-inflammatory feedback of this hormone and increases production of bone marrow-derived phagocytes that display GC resistance (Fig. 3) [200, 201]. This is consistent with the fact that the elevated blood levels of GCs induce a general expansion of the granulocyte lineages in the bone marrow [202]. Likewise, in humans, genome-wide expression microarrays of peripheral blood monocytes from chronical- 


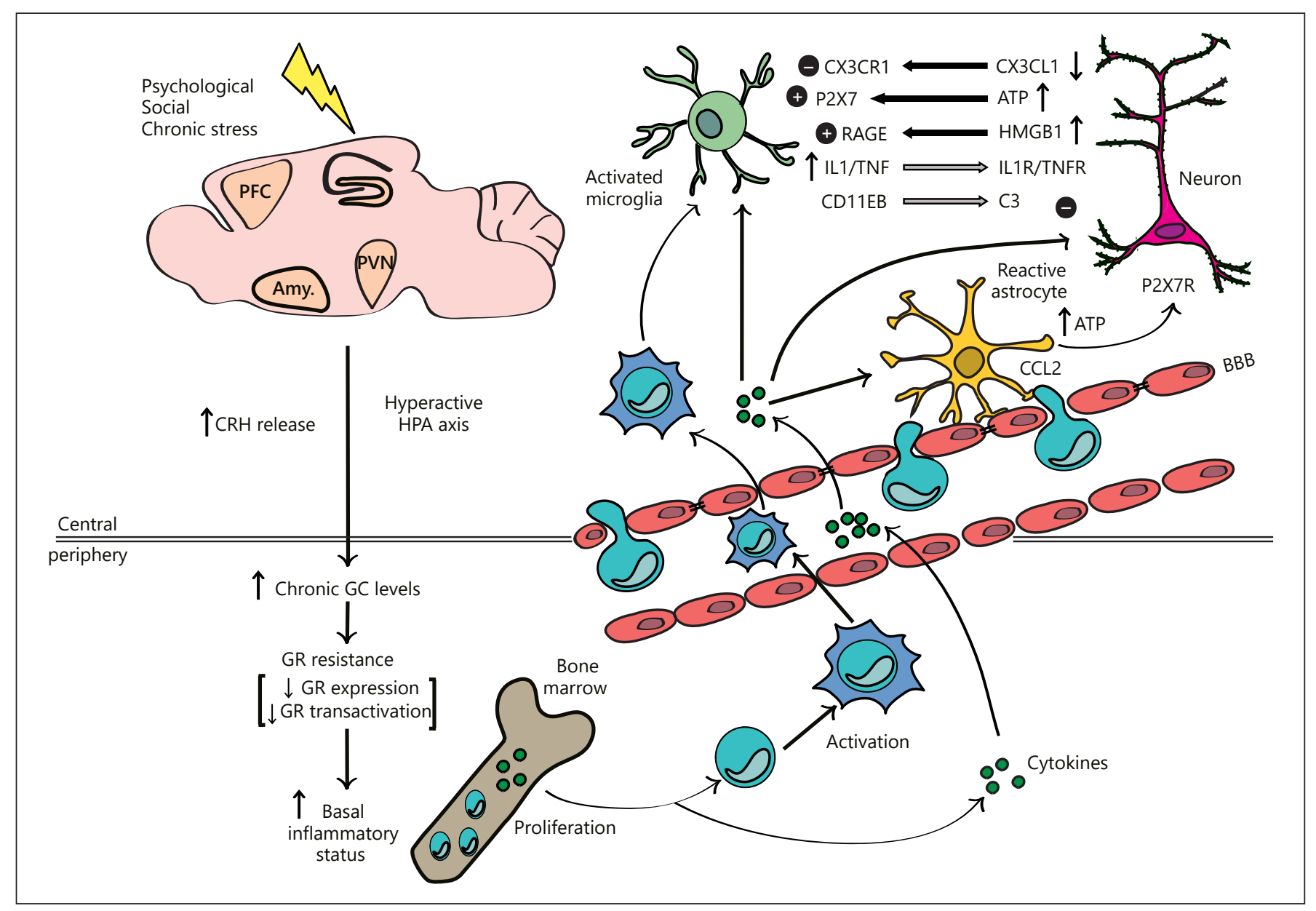

Fig. 3. The role of glucocorticoids and the microglia-neuron-astrocyte interactions in the chronic stressed brain. Stressful stimuli activate the adrenal cortex to release glucocorticoids (GCs). With prolonged exposure, GC release increases, leading to GC resistance that triggers an increase in the inflammatory status. Activated monocytes and cytokines traffic to the brain where they affect neuronal plasticity. Changes in neuronal synapsis such as the inhibition of CX3CL1 (fractalkine) expression are detected by microglia favoring cytokine release and monocyte recruitment. In turn, monocytes can acquire microglial properties. Sustained increased levels of cytokines cross the blood brain barrier (BBB) and activate microglia cells inducing persistent synaptic remodeling. Microglial activation and proinflammatory cytokine release contribute to the inhibition of astrocyte activity. Psychosocial stress also leads to the switch of microglia to a proinflammatory phenotype, which releases CC-chemokine ligand 2 (CCL2) that in turn attracts activated myeloid cells to the brain. Perturbations of the microglia/neuron interaction, have been reported in animal models of depression. These include the reduction in CX3CL1 and its receptor CX3CR1, and induction of high-mobility group box 1
(HMGB1) and ATP from reactive astrocytes. Many of these microglial activation pathways converge on the nucleotide-binding domain, leucine-rich-containing family, pyrin domain-containing-3 (NLRP3) inflammasome. The release of the proinflammatory cytokines IL- $1 \beta$ and TNF- $\alpha$ also elicits molecular changes in neurons. Astrocytes engulf synapses regulating synapse transmission, but at the same time they control BBB permeability and integrity. Upon activation, astrocytes express high levels of the chemokine CCL2 which, acting on its receptor (CCR2) on peripheral phagocytes, promotes the extravasation and infiltration of monocytes into the brain. A main activator of CCL2 expression is the $\mathrm{P} 2 \mathrm{X} 7$ receptor which is activated upon ATP release. P2X7R activation also promotes IL- $1 \beta$ release and inflammasome activation to trigger depression-like behavior. Exposure to chronic stress reduces the expression of CX3CL1 and CX3CR1. Another important effector molecule is the $\mathrm{C} 3$ complement protein, which triggers synaptic pruning by tagging targeted synapses to be phagocytosed by microglia. RAGE, receptor for advanced glycation end products. 
ly stressed individuals show increased stress-induced proinflammatory markers and diminished expression of transcripts bearing response elements for GCs [203].

Adult neurogenesis has also been hypothesized as a relevant mechanism in depression. It is clear that in rodents, chronic stress decreases proliferation and maturation of newborn neurons, and antidepressants exert opposite effects [204]. Seemingly, adult hippocampal neurogenesis would not be a major contributor to the development of depression but might contribute in a more restricted manner to specific anxiety-related symptoms [205]. On the other hand, ongoing adult neurogenesis in the hippocampus is necessary for the behavioral effects of antidepressant drugs in rodents [206]. However, its relevance and even its actual occurrence in the human brain have recently been put under debate [207-209], and therefore the actual potential role of the newborn neurons in the dentate gyrus in depression and antidepressant mechanism of action remain unclear.

In addition to the influence on adult neurogenesis, chronic stress paradigms also reduce dendritic arborization of CA1 pyramidal cells in the hippocampus, a phenomenon plausibly associated to a reduction in local BDNF levels [210-212]. Interestingly, early maternal separation paradigms also trigger long-lasting reduction in BDNF levels in the rat hippocampus [213].

Several studies have found that hippocampal BDNF expression is directly downregulated by GCs [214, 215] and antidepressant treatments can prevent stress-induced reduction of BDNF [216] as well as corticosteronemediated decrease in BDNF expression [217]. Mechanistically, antidepressants may exert their function by inducing acetylation of histone subunits around the BDNF gene promoter, thus leading to an increase in BDNF expression and production [216]. BDNF function is mediated by its binding to high-affinity receptor TrkB (tyrosine kinase B). However, a deficiency of BDNF or the Trk receptor does not induce depressed-like behaviors, suggesting that BDNF reduction per se is not sufficient to alter mood and that other concurrent factors are necessary to trigger depression $[218,219]$. Nevertheless, the antidepressant response does require an increase in BDNF activity and the associated structural recovery of the neuronal network [220-222].

Several in vivo studies demonstrated that inflammation causes a reduction of BDNF gene expression [223225]. These findings support the possibility that a cross talk between inflammatory mediators and neurotrophins contributes to the development of mood disorders by reducing BDNF-related neuroplasticity.

Neuroimmune and Inflammatory Signals in Complex Disorders of the CNS
The stress response can influence peripheral immune responses not only by means of humoral pathways but also through the fast actions of the autonomic nervous system. Sympathetic terminals profusely innervate primary and secondary lymphoid organs, and many immune cells express adrenergic receptors $[157,226]$. Increased catecholamine release leads to the proliferation and mobilization of hematopoietic cells in the bone marrow, and therefore regulating the influx of myeloid lineage immune cells $[176,177]$. When chronic social stress models are applied in rodents, this process contributes to an increase in circulating immature proinflammatory monocytes and granulocytes [227, 228] (Fig. 3).

Early life traumatic experiences in humans strongly influence the appearance of depressive symptoms later in life [148, 229]. Interestingly these long-lasting changes have also been verified at immune level suggesting that chronic stress-induced dysregulation of immunological parameters might be instrumental in the development of depression. Clinical studies have revealed that proinflammatory profile states are typically associated with low socioeconomic status but, remarkably, human individuals who experienced high levels of maternal warmth were protected from these long-lasting immunological changes [230]. Moreover, maltreated children showed a significant clinically relevant increase in plasma CRP levels 20 years later [231], and MDD patients with antecedents of early life stress show transcriptional changes in peripheral mononuclear cells that underlie susceptibility to hyperinflammatory responses [232]. Remarkably, a recent report from Khandaker et al. [233] described that high levels of IL-6 in childhood are associated with $10 \%$ higher risks of developing depression by 18 years in young adults. This longitudinal study shows for the first time that peripheral inflammation precedes depressive symptoms in at least a subpopulation of patients.

A still open but relevant question is as to how peripheral inflammation can impact brain circuits. A series of preclinical studies have addressed this relevant question. Different reports from Sheridan's group indicate that chronic social stress-induced anxiety is promoted by a direct recruitment of mononuclear cells to the brain mostly mediated by $\beta$-adrenergic inputs and facilitated by an IL-1-mediated leakage of the BBB [234-236]. On the other hand, blood-borne IL- $1 \beta$, IL- 6 , and TNF- $\alpha$ have been shown to cross the $\mathrm{BBB}$ via saturable transporters to enter cerebrospinal fluid and interstitial spaces of the brain [1] (Fig. 3). In a recent report, Hodes and coworkers [159] showed that irradiated mice transplanted with he-

Neuroimmunomodulation 2018;25:246-270 257 
matopoietic stem cells from mice previously subjected to repeated social defeat stress (RSCD) model displayed increased susceptibility to RSCD, whereas IL-6 KO bone marrow chimaeras remain resistant to stress. Interestingly from the clinical perspective, increased macrophage recruitment to the brain has been described in depressive suicides compared to controls [237].

Hence, both direct actions of cytokines and innate immune cells might help explain the detrimental influence of abnormal activation of peripheral immune cells on brain circuits and emotional behavior.

\section{Central Immune Signals in MDD and Animal Models} of Depression

Glial cells exert a multiplicity of functions in the healthy and diseased brain defining key developmental brain steps, and are involved in neuronal metabolism, synaptic transmission, repair, and survival [2]. Astrocytes, which actively respond to cytokines, engulf synapses sustaining and regulating synapse transmission, but at the same time their end feet control BBB permeability and integrity. Upon activation, astrocytes express and release high levels of the chemokine CCL2 which, acting on its receptor (CCR2) on peripheral phagocytes, promotes the extravasation and infiltration of monocytes into the brain [238]. Likewise increased CCL2 expression has been found in the anterior cingular cortex of postmortem samples of MDD patients who committed suicide [237].

The strategic location of astrocytes lining on brain capillaries and the high expression levels of the chemokine CCL2 help explain its role in stress-induced recruitment of peripheral phagocytes. A main activator of CCL2 expression is the purinergic multimeric P2X7R channel which is activated upon ATP release [239]. Interestingly, recent studies showed that the heterozygous expression of the genetic variant P2X7R-Gln460Arg is associated with mood disorders [240,241], and only the coexpression of both WT and 460 variants compromises the receptor function [242]. Recently, a humanized mouse model of this mutation has been developed [243], and mice that harbor both P2X7R variants showed alterations in their sleep quality resembling signs of a prodromal stage of depression. Besides CCL2, P2X7R activation also promotes IL- $1 \beta$ release and inflammasome activation to trigger depression-like behavior (Fig. 3) [244].

Plausibly, a mechanistic convergence between ATP/ P2X7R and CCL2-mediated monocyte recruitment might also take part in the development of MDD.
Reduced numbers of astrocytes have been found in brain regions controlling emotion in suicide victims [245], and both reduced number of astrocytes as well as decreased expression of GFAP have been found in rodent chronic stress models [245-247]. This suggests that after a first wave of astroglial activation, probably due to peripheral cytokines, chronic activation might impair astrocytic function, further affecting BBB permeability and support of neuronal metabolism.

Microglial cells are also reactive to psychological stress, and rodents subjected to chronic stress models display an increased number of activated microglial cells in limbic brain regions [234, 248]. Interestingly, HPA axis activation prime microglial proinflammatory response and both GC and glutamate signaling promote microglia proliferation upon restraint stress [179, 249]. Employing an inescapable stress model in rats, Weber et al. [250] recently showed that stress increases the high-mobility group box 1 (HMGB1) protein which further triggers proinflammatory cytokine secretion in microglia upon membrane-bound RAGE (receptor for advanced glycation end products).

Recent preclinical studies also provide evidence for a causal role of microglial activation in depressive states. The administration of minocycline, a well-known inhibitor of microglial activation, rescues the stress-induced depression-like behaviors [251]. On the other hand, recent studies suggest that the chemokine system CX3CL1CX3CR1 might also play a role in depressive-like behavior. Exposure to chronic social defeat stress reduces the expression of CX3CL1 and CX3CR1 [236]. Most importantly, mice lacking CX3CR1 are resilient to chronic unpredictable stress-induced anhedonia [252] and do not develop social stress-induced anxiety-like behaviors [236]. Another important effector molecule in microglial cells is the $\mathrm{C} 3$ complement protein, which triggers synaptic pruning during development by tagging targeted synapses to be further phagocytosed by microglia [253]. Further studies will surely address this issue in order to define the participation of this interesting mechanism in the development of mood disorders and depression.

Finally, postmortem analyses of brains from depressive patients show morphological changes compatible with microglial activation [254], and a recent positron emission tomography-based study shows greater microglial activation in prefrontal, insular, and anterior cingulate cortices [255]. 
Towards a Neuroimmune-Based Therapeutics of

$M D D$

Modern antidepressants have not substantially improved their efficacy compared to old drugs: they still require several weeks to exert their effects, side effects are still a significant problem, and a substantial proportion of patients respond only partially or remain completely resistant to medication $[145,147,148]$. The therapeutic role of anti-inflammatory drugs is still a matter of debate with studies showing either beneficial or detrimental effects of nonsteroidal anti-inflammatory drugs (NSAID) in patients treated with antidepressants [256, 257]. A large meta-analysis concludes that NSAID, but particularly the Cox-2 inhibitor celecoxib, have clinically relevant antidepressant effects with and without concomitant antidepressant medication [258], although the authors claim that conclusions should be taken with caution due to the high risk of bias and high heterogeneity of the studies. A large and ideally prospective study with a more homogenous group of patients will be necessary to solve this still open question.

Strategies directly targeting cytokines are under investigation. A double-blind placebo-controlled clinical trial showed that infliximab, a chimeric monoclonal antiTNF- $\alpha$ antibody, improves depressive symptoms in patients with high basal levels of inflammation [259]. Besides, two clinical trials will investigate the antidepressant actions of two different antibodies targeting IL-6, sirukumab (NCT02473289), and tocilizumab (NCT02660528) (www.clinicaltrials.gov).

Finally, new therapeutic opportunities might be related to P2X7R antagonists. Several compounds blocking these receptors have been patented in recent years [260] and might be interesting candidates to be tested in future clinical trials.

\section{Neural and Immune Networks Underlying Autism}

ASD are a group of neurological conditions in which affected individuals have compromised cognition related to social and communication skills, restriction or rigidity of interests, and present obsessive and repetitive behaviors. Clinically, immune comorbidities are commonly described in these disorders, while immune events during development increase autism incidence pointing both to an environmental component of ASD, as well as to a neuroimmune cross talk (Fig. 4). Evidence suggests that immune deregulation at prenatal or early postnatal development may result in specific brain circuitries that typify

Neuroimmune and Inflammatory Signals in Complex Disorders of the CNS autistic behavior as well as a characteristic immunological profile. Finally, a corollary of the fact that ASD is established during development is that immune cells and molecules are probably involved in CNS ontogenesis and functioning since, for example, IL-6 and its receptor mRNAs were described in neonatal rat brain neurons [261]. Neuronal expression of MHC molecules seem to affect regulation of synaptic densities and neural connectivity during development $[262,263]$, sensory and social cognition $[264,265]$, and, together with TNF- $\alpha$, affect homeostatic synaptic plasticity, a phenomenon by which neurons avoid neural network damage caused by chronic inactivity or hyperactivity [266].

Social interaction emerges in postnatal life and relies on a morphological scaffold that is structured in early intrauterine developmental stages and depends on intrinsic and extrinsic factors that properly form brain structure to function normally [267-274]. Mutations or biological imbalance disrupts this morphological assembly and produces mild or severe cognitive impairments $[275,276]$. In this sense, genetic [277-279] and environmental [280, 281] risk factors are described for ASD, and it is possible that they interact in some cases or at some level [262,263, $282]$ to generate the heterogeneous spectrum of disorders that comprise ASD. This interaction constitutes a third etiology that arises from two aspects: (1) autism risk genes establish a complex canonical network in which a mutation of a single component could disrupt many other related molecular pathways; (2) immune activation events during brain development are known to be a relevant environmental factor that induces gene expression changes in the developing brain and later CNS disorders [243].

The fetal and maternal organism interaction is vital but opens a vulnerability window for the developing fetus [266]. An increased frequency of autism cases after the rubella outbreak in the 1960s was the first clue that ASD and the immune system might be connected [283]. Still today, several studies have been unraveling this correlation with 3 perspectives: (1) outcomes of maternal immunological perturbation in offspring immunity, brain morphology, function, and behavior; (2) the abnormal humoral and cellular innate immune responses in autistic patients; (3) the participation of immune cells and molecules in CNS ontogenesis [284-287]. Here, we update clinical and research data that correlate immune system with ASD and brain development (Fig. 4).

\section{Evidence of Immunological ASD Etiology}

Experimental maternal immune activation (MIA) by viral, bacterial or proinflammatory insults showed that all 


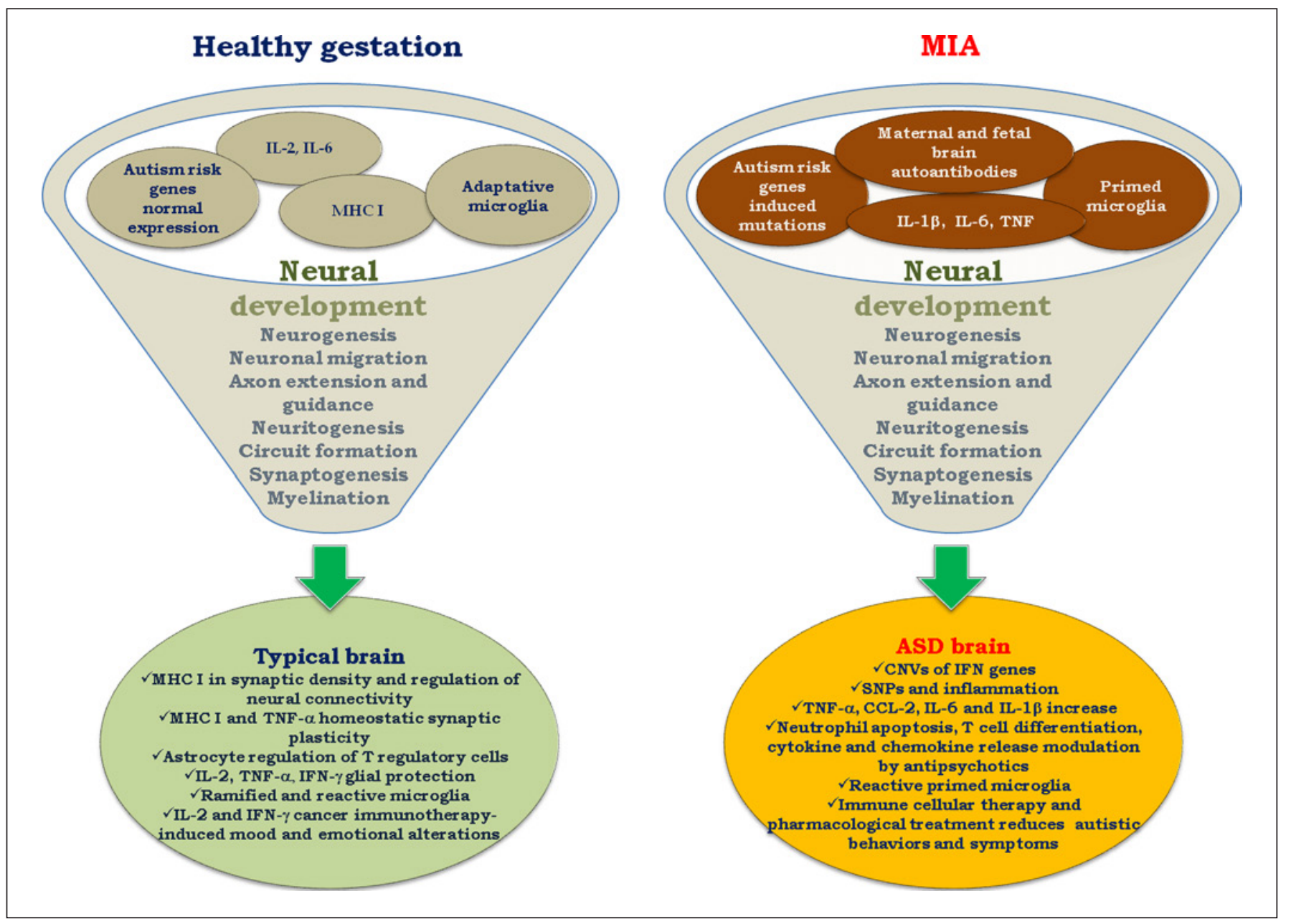

Fig. 4. Cross talk between the CNS and immune system in ASD. In the center, main ontogenic events of CNS development susceptible to immunological modulation. Immune system components normally participate in these processes in healthy gestation leading to a normal brain; therefore, immunological responses in maternal immune activation (MIA) can also interfere with neural develop- mental events which would lead to an ASD brain. IFN, interferon; $\mathrm{CNV}$, copy number variation; SNP, single nucleotide polymorphism; TNF- $\alpha$, tumor necrosis factor- $\alpha$; CCL-2, chemokine (CCmotif) ligand 2; IL, interleukin; MHC-I, major histocompatibility factor-I. these immunogens could change immune system gene transcripts in embryonic and postnatal brain, as well as brain and serum immune responses, with common and different features, but with specificity for CNS regions and developmental stages [288, 289]. Garbett et al. [289] suggested that MIA-elicited neuroprotective mechanisms lead to defective neural morphologies.

New data describe that MIA also deregulates, directly or indirectly, genes for general cell processes that have related functions or constitute a genetic cascade, and present high penetrance in ASD, such as the PTEN, Tsc2mTor-Eif4e, and FMRP genes [290]. MIA transient interference on the expression of each of these genes would be small, but the co-occurrence of multiple MIA-induced gene expression regulatory events associated with the higher frequency of MIA itself could cause a devastating effect comparable to their permanent individual mutations. These results speak in favor of the ASD genetic and environmental etiological crossway.

The autistic-like behaviors generated following immune activation in pregnant women and neonates are important clues to understanding immune etiology. In non-human primates, poly I:C-LC treatment of pregnant macaques induced long-term high responses of innate inflammatory cytokines and associated autistic behaviors with abnormal immune profile in offspring [291]. An- 
other recent work demonstrated that a LPS challenge in rodent neonates compromised immunity and neurochemical aspects of the prefrontal cortex, hippocampus, and hypothalamus in adolescent and adult animals [292]. Myeloperoxidase activity and IL-4 were higher, while IL-6 presented reduced levels in the LPS-challenged group. The alterations generated were not homogeneous between males and females for the 3 brain regions mentioned above in the different developmental stages evaluated since there were differences for the interactions of these 3 factors (IL-4, IL-6, and myeloperoxidase activity). Hippocampus also had higher BDNF levels in adults of both sexes and higher nitrite levels and lower parvalbumin expression in males. Depressive- and anxiety-like, repetitive and risk-taking behaviors and working memory impairments were also altered with specific sex- and age-related patterns congruent with these features in human ASD [293, 294]. The study also explored the critical aspect of the developmental time window susceptibility considering the nervous, immune, and brain-blood barrier ontogeny periods.

\section{Immune System in Autism}

The second aspect explored is the distinct immune profile detected in autistic patients and found in the different animal paradigms $[291,295]$. Serum IL-1 $\beta$ and IL-4 at birth, is associated with higher risk of ASD diagnosis in children and symptom stringency [296]. Antibodies, monocytes, $\mathrm{T}$ cell responses, and natural killer cells of autistic children were also found to be altered [291].

In the CNS, there is evidence that microglial cells are also implicated in autism [284, 297-299]. An experimental genetic autism paradigm revealed a transient reduction, during the first postnatal week, of the microglial marker Iba1 in the basolateral amygdala, one of main cerebral regions executing behaviors impaired in ASD [300]. The administration of the microglial modulator minocycline reverted this morphological phenotype without an effect on the high anxiety behaviors such as the increased maternal separation-induced ultrasonic vocalizations in the mutants [301].

Another experimental cue comes from data of immune therapy attenuating ASD behaviors in rodents of an environmental paradigm of the disorder [302]. In this work, the disorder was induced by the gestational treatment with the antiepileptic, anticonvulsant, and mood stabilizer drug valproic acid (VPA), known to raise the risk of treated pregnant women to generate autistic children $[302,303]$. The therapeutic target was histamine, a molecule that is active both in the immune and nervous systems $[304,305]$. The therapy consisted in the application of an acute dose of ciproxifan (CPX), an antagonist of the histamine receptor 3 (H3R), 30 min before behavioral tests with young mice from mothers treated or not with VPA during gestation. CPX reduced social impairments and repetitive behavior in VPA animals [306], suggesting a potential role of the histamine-H3R system in the expression of ASD-like behaviors in rodents.

\section{The Immune System during CNS Ontogeny}

During development, neurons express class I MHC molecules which regulate synaptic density and neural connectivity $[307,308]$ and use other immune-related molecules to avoid neural network damage caused by chronic inactivity or hyperactivity [309]. A clear evidence that immune system directly takes part in CNS ontogenesis is the MIA putative effect in impairing microglia to properly execute its protective function in mature CNS [310].

Microglial developmental time window and novel functions described for these cells in CNS ontogenesis indicate they may also play a relevant role in triggering ASD [311-313]. Microglial cells enter the developing brain before midgestation and spread out regulating early axon guidance events, for example; although they are known to have a prominent role in later stages mainly in refinement processes $[310,314]$. When present in postnatal neurogenic niches, they adopt more immature morphologies, and their detection is illusive since they do not display their typical markers [12]. In the adult brain, microglia regulates neural progenitor cell proliferation and survival after induction of neuroinflammation through the IL- $1 \beta$ and p53 pathway, affecting cell cycle and programmed cell death [315]. When analyzed in postmortem temporal cortex samples from typically developing and autistic individuals, the function-related morphologies of these cells showed that the primed phenotype, associated with synaptic plasticity, presented reduced density, while the ramified morphology, associated with the immune response, was increased, despite the comparable number of Iba-1-positive cells. These changes can be related to losses in sensory processing and social cognition as well as regional immunological weakening that increases dysfunction [316].

\section{Future Perspectives}

There is a vast body of clinical and experimental evidence strongly corroborating the immune system involvement in the etiology of ASD solely as an environ- 
mental factor as well as in genetic cases. The variability in specific aspects matches the heterogeneous symptomatology but is a difficulty for data collection. Therefore, despite their higher frequency compared with rare point mutations, the definition of an etiological mechanism is still a challenge. The complete comprehension of neuroimmune interactions in ASD is far from being achieved, and we expect convergent data will shorten this distance.

\section{General Conclusion}

In recent years, it has become more and more evident that a multiplicity of molecules originally found in cells of the immune system are expressed in the CNS not only in astrocytes and microglial cells but even in the neurons themselves [307, 308]. It seems obvious that these molecules have been "acquired" by neurons throughout evolution to be used in new cell-specific processes unrelated to the immune response. Similar phenomena can be found in the case of proteins from other intracellular machineries, such as molecules related to DNA replication or cell cycle controllers such as cyclins [317-319] that perform new molecular functions in the context of neuronal physiology. Thus, it is likely that the CNS has not only co-opted immune molecules to carry out new functions but also employ similar strategies to interact with microglia and astrocytes, cells that resemble peripheral phagocytes in many ways.

It is following that logic that we could probably understand why similar, or even sometimes the very same, cells, cytokines, neurohormones, or inflammatory mediators, exert critical pathophysiological roles in such a diversity of complex brain diseases with completely divergent etiological bases.

Since fluent communication occurs between the endocrine, immune, and central nervous systems, an activation of the inflammatory response can influence neuro-/ endocrine processes, and vice versa. Under physiological conditions, this cross talk operates as negative feedbacks to counterbalance potential overshooting of the responses and thus keeping homeostasis. It seems clear, however, that in pathological states these cross talks became misbalanced either reaching new "pathological" set points or even becoming feedbacks of positive and iterative valence.

If immune and inflammatory responses are the cause or consequence of these pathologies is a "chicken and egg" question that remains unsolved. However, it seems plausible that altered iterative loops more directly or in- directly involving immune signals lead to brain disorders upon chronicity. Under this scope, a general misbalance of these integrative communication systems per se, rather than the dysfunction of one specific molecular component, would stem on the mechanistic bases of complex brain disorders once the disease is installed. Thus, immune-based therapies might represent new avenues for pharmacological interventions that might exert both effects on direct cellular effectors and/or contribute to normalize altered neuro-endocrine-immune communication.

Probably, we have underestimated the relevance of these immune-related mechanisms in different brain disorders. From the basic research perspective, the advent of new "omics" technologies at single cell level will surely provide new insights on this topic. On the other hand, it is expected that new pharmacological studies are initiated in order to select promising compounds from the large list of drugs already designed for immunological purposes and incorporate them into new clinical trials aimed to evaluate the potential roles of these drugs on a variety of brain disorders and pathologies.

\section{Acknowledgments}

We thank Clara Sokn and Romina Gobbini for their help with the illustrations. This work was supported by grants from the Brazilian National Research Council (CNPq), Research Foundation of the State of Rio de Janeiro (FAPERJ), CAPES, PRONEX/MCT, and INCT/NIM (to C.A.S.); Agencia Nacional de Promoción Científica y Tecnológica (to A.C.L.); Volkswagen Stiftung, MinCyTBMBF Cooperation Program, Agencia Nacional de Promoción Científica y Tecnológica PICT-PRH (to D.R.); Agencia Nacional de Investigación e Innovación - Sistema Nacional de Investigadores (ANII-SNI) and Programa de Desarrollo de las Ciencias Básicas (PEDECIBA) to E.T. This work was performed in the frame and specially supported by Fondo para la Convergencia Estructural de Mercosur (COF 03/11).

\section{Disclosure Statement}

The authors declare no conflict of interest. 


\section{References}

1 Banks WA, Kastin AJ, Broadwell RD. Passage of cytokines across the blood-brain barrier. Neuroimmunomodulation. 1995 Jul-Aug; 2(4):241-8.

2 Barres BA. The mystery and magic of glia: a perspective on their roles in health and disease. Neuron. 2008 Nov;60(3):430-40.

3 Lynch MA. The multifaceted profile of activated microglia. Mol Neurobiol. 2009 Oct; 40(2):139-56.

4 Pachter JS, de Vries HE, Fabry Z. The bloodbrain barrier and its role in immune privilege in the central nervous system. J Neuropathol Exp Neurol. 2003 Jun;62(6):593-604.

5 Szmydynger-Chodobska J, Fox LM, Lynch KM, Zink BJ, Chodobski A. Vasopressin amplifies the production of proinflammatory mediators in traumatic brain injury. J Neurotrauma. 2010 Aug;27(8):1449-61.

6 Jacobs AH, Tavitian B; INMiND consortium. Noninvasive molecular imaging of neuroinflammation. J Cereb Blood Flow Metab. 2012 Jul;32(7):1393-415.

7 Olah M, Biber K, Vinet J, Boddeke HW. Microglia phenotype diversity. CNS Neurol Disord Drug Targets. 2011 Feb;10(1):108-18.

8 Kettenmann $\mathrm{H}$, Hanisch UK, Noda M, Verkhratsky A. Physiology of microglia. Physiol Rev. 2011 Apr;91(2):461-553.

9 London A, Cohen M, Schwartz M. Microglia and monocyte-derived macrophages: functionally distinct populations that act in concert in CNS plasticity and repair. Front Cell Neurosci. 2013 Apr;7:34.

10 Schulte-Herbrüggen $\mathrm{O}$, Nassenstein C, Lommatzsch M, Quarcoo D, Renz H, Braun A. Tumor necrosis factor-alpha and interleukin- 6 regulate secretion of brain-derived neurotrophic factor in human monocytes. J Neuroimmunol. 2005 Mar; 160(1-2):204-9.

11 Kuno R, Yoshida Y, Nitta A, Nabeshima T, Wang J, Sonobe Y, et al. The role of TNF-alpha and its receptors in the production of NGF and GDNF by astrocytes. Brain Res. 2006 Oct;1116(1):12-8.

12 Xavier AL, Menezes JR, Goldman SA, Nedergaard M. Fine-tuning the central nervous system: microglial modelling of cells and synapses. Philos Trans R Soc Lond B Biol Sci. 2014 Oct;369(1654):20130593.

13 Burda JE, Sofroniew MV. Reactive gliosis and the multicellular response to CNS damage and disease. Neuron. 2014 Jan;81(2):229-48.

14 Liu W, Tang Y, Feng J. Cross talk between activation of microglia and astrocytes in pathological conditions in the central nervous system. Life Sci. 2011 Aug;89(5-6):141-6.

15 Kierdorf K, Prinz M. Factors regulating microglia activation. Front Cell Neurosci. 2013 Apr; 7:44.

16 Šišková Z, Tremblay ME. Microglia and synapse: interactions in health and neurodegeneration. Neural Plast. 2013;2013:425845.
17 Furman JL, Norris CM. Calcineurin and glial signaling: neuroinflammation and beyond. J Neuroinflammation. 2014 Sep;11(1):158.

18 Nagamoto-Combs K, Combs CK. Microglial phenotype is regulated by activity of the transcription factor, NFAT (nuclear factor of activated T cells). J Neurosci. 2010 Jul;30(28): 9641-6.

19 Dissing-Olesen L, LeDue JM, Rungta RL, Hefendehl JK, Choi HB, MacVicar BA. Activation of neuronal NMDA receptors triggers transient ATP-mediated microglial process outgrowth. J Neurosci. 2014 Aug;34(32): 10511-27.

20 Li Y, Du XF, Liu CS, Wen ZL, Du JL. Reciprocal regulation between resting microglial dynamics and neuronal activity in vivo. Dev Cell. 2012 Dec;23(6):1189-202.

21 Jones RS, Lynch MA. How dependent is synaptic plasticity on microglial phenotype? Neuropharmacology. 2015 Sep;96 Pt A:3-10.

22 Shi J, Townsend M, Constantine-Paton $M$. Activity-dependent induction of tonic calcineurin activity mediates a rapid developmental downregulation of NMDA receptor currents. Neuron. 2000 Oct;28(1):103-14.

23 Nichols RA, Suplick GR, Brown JM. Calcineurin-mediated protein dephosphorylation in brain nerve terminals regulates the release of glutamate. J Biol Chem. 1994 Sep;269(38): 23817-23.

24 Wiley JS, Sluyter R, Gu BJ, Stokes L, Fuller SJ. The human P2X7 receptor and its role in innate immunity. Tissue Antigens. 2011 Nov: 78(5):321-32.

25 Pozzi D, Menna E, Canzi A, Desiato G, Mantovani C, Matteoli M. The Communication Between the Immune and Nervous Systems: The Role of IL- $1 \beta$ in Synaptopathies. Front Mol Neurosci. 2018 Apr;11:111.

26 Rosenberg GA: Extracellular matrix inflammation in vascular cognitive impairment and dementia. Clin Sci (London) 2017;131:425437.

27 Wang YW, Zhou Q, Zhang X, Qian QQ, Xu JW, Ni PF, et al. Mild endoplasmic reticulum stress ameliorates lipopolysaccharide-induced neuroinflammation and cognitive impairment via regulation of microglial polarization. J Neuroinflammation. 2017 Nov; 14(1):233.

28 Berardi N, Pizzorusso T, Maffei L. Critical periods during sensory development. Curr Opin Neurobiol. 2000 Feb;10(1):138-45.

29 Levelt CN, Hübener M. Critical-period plasticity in the visual cortex. Annu Rev Neurosci. 2012;35(1):309-30.

$30 \mathrm{Kaas} \mathrm{JH}$. The reorganization of somatosensory and motor cortex after peripheral nerve or spinal cord injury in primates. Prog Brain Res. 2000;128:173-9.

31 Serfaty CA, Campello-Costa P, Linden R. Rapid and long-term plasticity in the neonatal and adult retinotectal pathways following a retinal lesion. Brain Res Bull. 2005 Jul;66(2): 128-34.
32 Vasques JF, Heringer PV, Gonçalves RG, Campello-Costa P, Serfaty CA, Faria-Melibeu $\mathrm{AD}$. Monocular denervation of visual nuclei modulates APP processing and sAPPa production: A possible role on neural plasticity. Int J Dev Neurosci. 2017 Aug;60:16-25.

33 Toldi J, Fehér O, Wolff JR. Neuronal plasticity induced by neonatal monocular (and binocular) enucleation. Prog Neurobiol. 1996 Feb;48(3):191-218

34 Carmichael ST, Kathirvelu B, Schweppe CA, Nie EH. Molecular, cellular and functional events in axonal sprouting after stroke. Exp Neurol. 2017 Jan;287(Pt 3):384-94.

35 Caleo M. Rehabilitation and plasticity following stroke: insights from rodent models. Neuroscience. 2015 Dec;311:180-94.

36 Gonzalez D, Satriotomo I, Miki T, Lee KY, Yokoyama T, Touge T, et al. Changes of parvalbumin immunoreactive neurons and GFAP immunoreactive astrocytes in the rat lateral geniculate nucleus following monocular enucleation. Neurosci Lett. 2006 Mar: 395(2):149-54.

37 Wilms P, Bähr M. Reactive changes in the adult rat superior colliculus after deafferentation. Restor Neurol Neurosci. 1995 Jan;9(1):21-34.

38 Bechmann I, Nitsch R. Involvement of nonneuronal cells in entorhinal-hippocampal reorganization following lesions. Ann N Y Acad Sci. 2000 Jun;911(1):192-206.

39 Kaur C, Rathnasamy G, Ling EA. Biology of Microglia in the Developing Brain. J Neuropathol Exp Neurol. 2017 Sep;76(9):736-53.

40 Wu Y, Dissing-Olesen L, MacVicar BA, Stevens B. Microglia: Dynamic Mediators of Synapse Development and Plasticity. Trends Immunol. 2015 Oct;36(10):605-13.

41 Ngu EM, Sahley CL, Muller KJ. Reduced axon sprouting after treatment that diminishes microglia accumulation at lesions in the leech CNS. J Comp Neurol. 2007 Jul;503(1):101-9.

42 Chan Y, Yoon J, Wu JT, Kim HJ, Pan KT, Yim J, et al. DEN1 deneddylates non-cullin proteins in vivo. J Cell Sci. 2008 Oct;121(Pt 19): 3218-23.

43 Batchelor PE, Liberatore GT, Porritt MJ, Donnan GA, Howells DW. Inhibition of brain-derived neurotrophic factor and glial cell line-derived neurotrophic factor expression reduces dopaminergic sprouting in the injured striatum. Eur J Neurosci. 2000 Oct; 12(10):3462-8

44 Woods AG, Guthrie KM, Kurlawalla MA, Gall CM. Deafferentation-induced increases in hippocampal insulin-like growth factor-1 messenger RNA expression are severely attenuated in middle aged and aged rats. Neuroscience. 1998 Apr;83(3):663-8.

45 Shohami E, Gallily R, Mechoulam R, Bass R, Ben-Hur T. Cytokine production in the brain following closed head injury: dexanabinol (HU-211) is a novel TNF-alpha inhibitor and an effective neuroprotectant. J Neuroimmunol. 1997 Feb;72(2):169-77. 
46 Oshima T, Lee S, Sato A, Oda S, Hirasawa H, Yamashita T. TNF-alpha contributes to axonal sprouting and functional recovery following traumatic brain injury. Brain Res. 2009 Sep;1290:102-10.

47 Kreutz MR, Weise J, Dieterich DC, Kreutz M, Balczarek P, Böckers TM, et al. Rearrangement of the retino-collicular projection after partial optic nerve crush in the adult rat. Eur J Neurosci. 2004 Jan;19(2):247-57.

48 Narducci R, Baroncelli L, Sansevero G, Begenisic T, Prontera C, Sale A, et al. Early impoverished environment delays the maturation of cerebral cortex. Sci Rep. 2018 Jan;8(1): 1187.

49 Tognini P, Manno I, Bonaccorsi J, Cenni MC, Sale A, Maffei L. Environmental enrichment promotes plasticity and visual acuity recovery in adult monocular amblyopic rats. PLoS One. 2012;7(4):e34815.

50 Parkhurst CN, Yang G, Ninan I, Savas JN, Yates JR 3rd, Lafaille JJ, et al. Microglia promote learning-dependent synapse formation through brain-derived neurotrophic factor. Cell. 2013 Dec;155(7):1596-609.

51 Hakkoum D, Stoppini L, Muller D. Interleukin-6 promotes sprouting and functional recovery in lesioned organotypic hippocampal slice cultures. J Neurochem. 2007 Feb;100(3): 747-57.

52 Ramer MS, Murphy PG, Richardson PM, Bisby MA. Spinal nerve lesion-induced mechanoallodynia and adrenergic sprouting in sensory ganglia are attenuated in interleukin-6 knockout mice. Pain. 1998 Nov;78(2):115-21.

53 Tachida Y, Nakagawa K, Saito T, Saido TC, Honda T, Saito Y, et al. Interleukin-1 beta upregulates TACE to enhance alpha-cleavage of APP in neurons: resulting decrease in Abeta production. J Neurochem. 2008 Mar;104(5): 1387-93.

54 Oliveira-Silva P, Jurgilas PB, Trindade P, Campello-Costa P, Perales J, Savino W, et al. Matrix metalloproteinase-9 is involved in the development and plasticity of retinotectal projections in rats. Neuroimmunomodulation. 2007;14(3-4):144-9.

55 Czeh M, Gressens P, Kaindl AM. The yin and yang of microglia. Dev Neurosci. 2011;33(34):199-209.

56 Okada S, Nakamura M, Katoh H, Miyao T, Shimazaki T, Ishii K, et al. Conditional ablation of Stat 3 or Socs 3 discloses a dual role for reactive astrocytes after spinal cord injury. Nat Med. 2006 Jul;12(7):829-34.

57 Herrmann JE, Imura T, Song B, Qi J, Ao Y, Nguyen TK, et al. STAT3 is a critical regulator of astrogliosis and scar formation after spinal cord injury. J Neurosci. 2008 Jul;28(28):723143.

58 Renault-Mihara F, Okada S, Shibata S, Nakamura M, Toyama Y, Okano H. Spinal cord injury: emerging beneficial role of reactive astrocytes' migration. Int J Biochem Cell Biol. 2008;40(9):1649-53.
59 Davies SJ, Goucher DR, Doller C, Silver J. Robust regeneration of adult sensory axons in degenerating white matter of the adult rat spinal cord. J Neurosci. 1999 Jul;19(14):5810-22.

60 Goldshmit Y, Galea MP, Wise G, Bartlett PF, Turnley AM. Axonal regeneration and lack of astrocytic gliosis in EphA4-deficient mice. J Neurosci. 2004 Nov;24(45):10064-73.

61 McKeon RJ, Jurynec MJ, Buck CR. The chondroitin sulfate proteoglycans neurocan and phosphacan are expressed by reactive astrocytes in the chronic CNS glial scar. J Neurosci. 1999 Dec;19(24):10778-88.

62 Overman JJ, Clarkson AN, Wanner IB, Overman WT, Eckstein I, Maguire JL, et al. A role for ephrin-A5 in axonal sprouting, recovery, and activity-dependent plasticity after stroke. Proc Natl Acad Sci USA. 2012 Aug;109(33): E2230-9.

63 Cho KS, Yang L, Lu B, Feng Ma H, Huang X, Pekny M, et al. Re-establishing the regenerative potential of central nervous system axons in postnatal mice. J Cell Sci. 2005 Mar; 118(Pt 5):863-72.

64 Menet V, Prieto M, Privat A, Giménez y Ribotta M. Axonal plasticity and functional recovery after spinal cord injury in mice deficient in both glial fibrillary acidic protein and vimentin genes. Proc Natl Acad Sci USA. 2003 Jul;100(15):8999-9004.

65 Zamanian JL, Xu L, Foo LC, Nouri N, Zhou L, Giffard RG, et al. Genomic analysis of reactive astrogliosis. J Neurosci. 2012 May;32(18): 6391-410.

66 Liddelow SA, Barres BA. Reactive Astrocytes: Production, Function, and Therapeutic Potential. Immunity. 2017 Jun;46(6):957-67.

67 Xia XG, Hofmann HD, Deller T, Kirsch M. Induction of STAT3 signaling in activated astrocytes and sprouting septal neurons following entorhinal cortex lesion in adult rats. Mol Cell Neurosci. 2002 Nov;21(3):379-92.

68 Dehn D, Burbach GJ, Schäfer R, Deller T. NG2 upregulation in the denervated rat fascia dentata following unilateral entorhinal cortex lesion. Glia. 2006 Apr;53(5):491-500.

69 Bush TG, Puvanachandra N, Horner CH, Polito A, Ostenfeld T, Svendsen CN, et al. Leukocyte infiltration, neuronal degeneration, and neurite outgrowth after ablation of scar-forming, reactive astrocytes in adult transgenic mice. Neuron. 1999 Jun;23(2): 297-308.

70 Mayeux R. Epidemiology of neurodegeneration. Annu Rev Neurosci. 2003;26(1):81-104.

71 Ferri CP, Prince M, Brayne C, Brodaty H, Fratiglioni L, Ganguli M, et al.; Alzheimer's Disease International. Global prevalence of dementia: a Delphi consensus study. Lancet. 2005 Dec;366(9503):2112-7.

72 Elbaz A, Bower JH, Maraganore DM, McDonnell SK, Peterson BJ, Ahlskog JE, et al. Risk tables for parkinsonism and Parkinson's disease. J Clin Epidemiol. 2002 Jan;55(1):2531.
73 Ransohoff RM. How neuroinflammation contributes to neurodegeneration. Science. 2016 Aug;353(6301):777-83.

74 Glass CK, Saijo K, Winner B, Marchetto MC, Gage FH. Mechanisms underlying inflammation in neurodegeneration. Cell. 2010 Mar; 140(6):918-34.

75 Aktas O, Ullrich O, Infante-Duarte C, Nitsch $\mathrm{R}$, Zipp F. Neuronal damage in brain inflammation. Arch Neurol. 2007 Feb;64(2):185-9.

76 Raoul C, Estévez AG, Nishimune H, Cleveland DW, deLapeyrière $\mathrm{O}$, Henderson $\mathrm{CE}$, et al. Motoneuron death triggered by a specific pathway downstream of Fas. potentiation by ALS-linked SOD1 mutations. Neuron. 2002 Sep;35(6): 1067-83.

77 Raoul C, Buhler E, Sadeghi C, Jacquier A, Aebischer P, Pettmann B, et al. Chronic activation in presymptomatic amyotrophic lateral sclerosis (ALS) mice of a feedback loop involving Fas, Daxx, and FasL. Proc Natl Acad Sci USA. 2006 Apr;103(15):6007-12.

78 Olsson T, Kristensson K, Ljungdahl A, Maehlen J, Holmdahl R, Klareskog L. Gamma-interferon-like immunoreactivity in axotomized rat motor neurons. J Neurosci. 1989 Nov;9(11):3870-5.

79 Felger JC, Li Z, Haroon E, Woolwine BJ, Jung $\mathrm{MY}, \mathrm{Hu} \mathrm{X}$, et al. Inflammation is associated with decreased functional connectivity within corticostriatal reward circuitry in depression. Mol Psychiatry. 2016 Oct;21(10):1358-65.

80 Katsuno M, Adachi H, Banno H, Suzuki K, Tanaka F, Sobue G. Transforming growth factor- $\beta$ signaling in motor neuron diseases. Curr Mol Med. 2011 Feb;11(1):48-56.

81 Trias E, Ibarburu S, Barreto-Núñez R, Barbeito L. Significance of aberrant glial cell phenotypes in pathophysiology of amyotrophic lateral sclerosis. Neurosci Lett. 2017 Jan;636: 27-31.

82 Barbeito LH, Pehar M, Cassina P, Vargas MR, Peluffo H, Viera L, et al. A role for astrocytes in motor neuron loss in amyotrophic lateral sclerosis. Brain Res Brain Res Rev. 2004 Dec; 47(1-3):263-74.

83 Phani S, Re DB, Przedborski S. The Role of the Innate Immune System in ALS. Front Pharmacol. 2012 Aug;3:150.

84 McCombe PA, Henderson RD. The Role of immune and inflammatory mechanisms in ALS. Curr Mol Med. 2011 Apr;11(3):246-54.

85 Puentes F, Malaspina A, van Noort JM, Amor S. Non-neuronal cells in ALS: role of glial, immune cells and blood-CNS barriers. Brain Pathol. 2016 Mar;26(2):248-57.

86 Maragakis NJ, Rothstein JD. Mechanisms of Disease: astrocytes in neurodegenerative disease. Nat Clin Pract Neurol. 2006 Dec;2(12): 679-89.

87 Bollaerts I, Van Houcke J, Andries L, De Groef L, Moons L. Neuroinflammation as Fuel for Axonal Regeneration in the Injured Vertebrate Central Nervous System. Mediators Inflamm. 2017;2017:9478542. 
88 Engelhardt B, Coisne C. Fluids and barriers of the CNS establish immune privilege by confining immune surveillance to a twowalled castle moat surrounding the CNS castle. Fluids Barriers CNS. 2011 Jan;8(1):4.

89 Varvel NH, Neher JJ, Bosch A, Wang W, Ransohoff RM, Miller RJ, et al. Infiltrating monocytes promote brain inflammation and exacerbate neuronal damage after status epilepticus. Proc Natl Acad Sci USA. 2016 Sep;113(38):E5665-74.

90 Herz J, Filiano AJ, Smith A, Yogev N, Kipnis J. Myeloid Cells in the Central Nervous System. Immunity. 2017 Jun;46(6):943-56.

91 Jiang W, St-Pierre S, Roy P, Morley BJ, Hao J,Simard AR. Infiltration ofCCR2+Ly6Chigh Proinflammatory Monocytes and Neutrophils into the Central Nervous System Is Modulated by Nicotinic Acetylcholine Receptors in a Model of Multiple Sclerosis. J Immunol. 2016 Mar;196(5):2095-108.

92 Engelhardt JI, Tajti J, Appel SH. Lymphocytic infiltrates in the spinal cord in amyotrophic lateral sclerosis. Arch Neurol. 1993 Jan;50(1):30-6.

93 Brown RH, Al-Chalabi A. Amyotrophic Lateral Sclerosis. N Engl J Med. 2017 Jul;377(2): 162-72.

94 Chiu IM, Phatnani H, Kuligowski M, Tapia JC, Carrasco MA, Zhang M, et al. Activation of innate and humoral immunity in the peripheral nervous system of ALS transgenic mice. Proc Natl Acad Sci USA. 2009 Dec; 106(49):20960-5.

95 Bailly A, Perrin A, Bou Malhab LJ, Pion E, Larance M, Nagala M, et al. The NEDD8 inhibitor MLN4924 increases the size of the nucleolus and activates p53 through the ribosomal-Mdm2 pathway. Oncogene. 2016 Jan;35(4):415-26

96 Khalid SI, Ampie L, Kelly R, Ladha SS, Dardis C. Immune Modulation in the Treatment of Amyotrophic Lateral Sclerosis: A Review of Clinical Trials. Front Neurol. 2017 Sep;8:486.

97 Petrov D, Mansfield C, Moussy A, Hermine O. ALS Clinical Trials Review: 20 Years of Failure. Are We Any Closer to Registering a New Treatment? Front Aging Neurosci. 2017 Mar;9:68.

98 Cassina P, Peluffo H, Pehar M, MartinezPalma L, Ressia A, Beckman JS, et al. Peroxynitrite triggers a phenotypic transformation in spinal cord astrocytes that induces motor neuron apoptosis. J Neurosci Res. 2002 Jan;67(1):21-9.

99 Sofroniew MV. Molecular dissection of reactive astrogliosis and glial scar formation. Trends Neurosci. 2009 Dec;32(12):638-47.

100 Sofroniew MV, Vinters HV. Astrocytes: biology and pathology. Acta Neuropathol. 2010 Jan;119(1):7-35.

101 Rothstein JD, Van Kammen M, Levey AI, Martin LJ, Kuncl RW. Selective loss of glial glutamate transporter GLT-1 in amyotrophic lateral sclerosis. Ann Neurol. 1995 Jul;38(1):73-84.
102 Howland DS, Liu J, She Y, Goad B, Maragakis NJ, Kim B, et al. Focal loss of the glutamate transporter EAAT2 in a transgenic rat model of SOD1 mutant-mediated amyotrophic lateral sclerosis (ALS). Proc Natl Acad Sci USA. 2002 Feb;99(3):1604-9.

103 Wong PC, Pardo CA, Borchelt DR, Lee MK, Copeland NG, Jenkins NA, et al. An adverse property of a familial ALS-linked SOD1 mutation causes motor neuron disease characterized by vacuolar degeneration of mitochondria. Neuron. 1995 Jun;14(6):1105-16.

104 Dal Canto MC, Gurney ME. Neuropathological changes in two lines of mice carrying a transgene for mutant human $\mathrm{Cu}, \mathrm{Zn} \mathrm{SOD}$, and in mice overexpressing wild type human SOD: a model of familial amyotrophic lateral sclerosis (FALS). Brain Res. 1995 Apr; 676(1):25-40.

105 Pehar M, Vargas MR, Cassina P, Barbeito AG, Beckman JS, Barbeito L. Complexity of astrocyte-motor neuron interactions in amyotrophic lateral sclerosis. Neurodegener Dis. 2005;2(3-4):139-46.

106 Gandelman M, Levy M, Cassina P, Barbeito L, Beckman JS. P2X7 receptor-induced death of motor neurons by a peroxynitrite/ FAS-dependent pathway. J Neurochem. 2013 Aug;126(3):382-8.

107 Dhabhar FS, Malarkey WB, Neri E, McEwen BS. Stress-induced redistribution of immune cells-from barracks to boulevards to battlefields: a tale of three hormones-Curt Richter Award winner. Psychoneuroendocrinology. 2012 Sep;37(9):1345-68.

108 Labeur M, Refojo D, Wölfel B, Stalla J, Vargas $\mathrm{V}$, Theodoropoulou $\mathrm{M}$, et al. Interferongamma inhibits cellular proliferation and ACTH production in corticotroph tumor cells through a novel janus kinases-signal transducer and activator of transcription $1 /$ nuclear factor-kappa B inhibitory signaling pathway. J Endocrinol. 2008 Nov;199(2): $177-89$.

109 Pehar M, Cassina P, Vargas MR, Xie Y, Beckman JS, Massa SM, et al. Modulation of p75-dependent motor neuron death by a small non-peptidyl mimetic of the neurotrophin loop 1 domain. Eur J Neurosci. 2006 Sep;24(6):1575-80.

110 Bussmann KA, Sofroniew MV. Re-expression of p75NTR by adult motor neurons after axotomy is triggered by retrograde transport of a positive signal from axons regrowing through damaged or denervated peripheral nerve tissue. Neuroscience. 1999; 91(1):273-81.

111 Kerkhoff H, Jennekens FG, Troost D, Veldman $\mathrm{H}$. Nerve growth factor receptor immunostaining in the spinal cord and peripheral nerves in amyotrophic lateral sclerosis. Acta Neuropathol. 1991;81(6):649-56.

112 Seeburger JL, Tarras S, Natter H, Springer JE. Spinal cord motoneurons express p75NGFR and p145trkB mRNA in amyotrophic lateral sclerosis. Brain Res. 1993 Sep; 621(1):111-5
113 Haidet-Phillips AM, Hester ME, Miranda CJ, Meyer K, Braun L, Frakes A, et al. Astrocytes from familial and sporadic ALS patients are toxic to motor neurons. Nat Biotechnol. 2011 Aug;29(9):824-8.

114 Nagai M, Re DB, Nagata T, Chalazonitis A, Jessell TM, Wichterle $\mathrm{H}$, et al. Astrocytes expressing ALS-linked mutated SOD1 release factors selectively toxic to motor neurons. Nat Neurosci. 2007 May;10(5):615-22.

115 Cavadini S, Fischer ES, Bunker RD, Potenza A, Lingaraju GM, Goldie KN, et al. CullinRING ubiquitin E3 ligase regulation by the COP9 signalosome. Nature. 2016 Mar; 531(7596):598-603.

116 Chen LL. The biogenesis and emerging roles of circular RNAs. Nat Rev Mol Cell Biol. 2016 Apr;17(4):205-11.

117 Perry VH, Teeling J. Microglia and macrophages of the central nervous system: the contribution of microglia priming and systemic inflammation to chronic neurodegeneration. Semin Immunopathol. 2013 Sep; 35(5):601-12.

118 Moisse K, Strong MJ. Innate immunity in amyotrophic lateral sclerosis. Biochim Biophys Acta. 2006 Nov-Dec;1762(11-12): 1083-93.

119 Brownell JE, Sintchak MD, Gavin JM, Liao H, Bruzzese FJ, Bump NJ, et al. Substrateassisted inhibition of ubiquitin-like proteinactivating enzymes: the NEDD8 E1 inhibitor MLN4924 forms a NEDD8-AMP mimetic in situ. Mol Cell. 2010 Jan;37(1):102-11.

120 Trias E, Díaz-Amarilla P, Olivera-Bravo S, Isasi E, Drechsel DA, Lopez N, et al. Phenotypic transition of microglia into astrocytelike cells associated with disease onset in a model of inherited ALS. Front Cell Neurosci. 2013 Dec;7:274.

121 Fendrick SE, Xue QS, Streit WJ. Formation of multinucleated giant cells and microglial degeneration in rats expressing a mutant $\mathrm{Cu} / \mathrm{Zn}$ superoxide dismutase gene. J Neuroinflammation. 2007 Feb;4(1):9.

122 Frakes AE, Ferraiuolo L, Haidet-Phillips AM, Schmelzer L, Braun L, Miranda CJ, et al. Microglia induce motor neuron death via the classical NF- $\kappa$ B pathway in amyotrophic lateral sclerosis. Neuron. 2014 Mar;81(5): 1009-23.

123 Brites D, Vaz AR. Microglia centered pathogenesis in ALS: insights in cell interconnectivity. Front Cell Neurosci. 2014 May;8:117.

124 Boillée S, Yamanaka K, Lobsiger CS, Copeland NG, Jenkins NA, Kassiotis G, et al. Onset and progression in inherited ALS determined by motor neurons and microglia. Science. 2006 Jun;312(5778):1389-92.

125 Liao B, Zhao W, Beers DR, Henkel JS, Appel $\mathrm{SH}$. Transformation from a neuroprotective to a neurotoxic microglial phenotype in a mouse model of ALS. Exp Neurol. 2012 Sep; 237(1):147-52. 
126 Kriz J, Nguyen MD, Julien JP. Minocycline slows disease progression in a mouse model of amyotrophic lateral sclerosis. Neurobiol Dis. 2002 Aug;10(3):268-78.

127 Gordon PH, Moore DH, Miller RG, Florence JM, Verheijde JL, Doorish C, et al.; Western ALS Study Group. Efficacy of minocycline in patients with amyotrophic lateral sclerosis: a phase III randomised trial. Lancet Neurol. 2007 Dec;6(12):1045-53.

128 Díaz-Amarilla P, Olivera-Bravo S, Trias E, Cragnolini A, Martínez-Palma L, Cassina P, et al. Phenotypically aberrant astrocytes that promote motoneuron damage in a model of inherited amyotrophic lateral sclerosis. Proc Natl Acad Sci USA. 2011 Nov;108(44): 18126-31.

129 Trias E, Ibarburu S, Barreto-Núñez R, Babdor J, Maciel TT, Guillo M, et al. Post-paralysis tyrosine kinase inhibition with masitinib abrogates neuroinflammation and slows disease progression in inherited amyotrophic lateral sclerosis. J Neuroinflammation. 2016 Jul;13(1):177.

130 Butovsky O, Siddiqui S, Gabriely G, Lanser AJ, Dake B, Murugaiyan G, et al. Modulating inflammatory monocytes with a unique microRNA gene signature ameliorates murine ALS. J Clin Invest. 2012 Sep;122(9):3063-87.

131 Graves MC, Fiala M, Dinglasan LA, Liu NQ, Sayre J, Chiappelli F, et al. Inflammation in amyotrophic lateral sclerosis spinal cord and brain is mediated by activated macrophages, mast cells and T cells. Amyotroph Lateral Scler Other Motor Neuron Disord. 2004 Dec;5(4):213-9.

132 Murdock BJ, Bender DE, Kashlan SR, Figueroa-Romero C, Backus C, Callaghan $\mathrm{BC}$, et al. Increased ratio of circulating neutrophils to monocytes in amyotrophic lateral sclerosis. Neurol Neuroimmunol Neuroinflamm. 2016 Jun;3(4):e242.

133 Fiala M, Chattopadhay M, La Cava A, Tse E, Liu G, Lourenco E, et al. IL-17A is increased in the serum and in spinal cord CD8 and mast cells of ALS patients. J Neuroinflammation. 2010 Nov;7(1):76.

134 Nardo G, Trolese MC, de Vito G, Cecchi R, Riva N, Dina G, et al. Immune response in peripheral axons delays disease progression in SOD1G93A mice. J Neuroinflammation. 2016 Oct;13(1):261.

135 Alsuliman A, Appel SH, Beers DR, Basar R, Shaim H, Kaur I, et al. A robust, good manufacturing practice-compliant, clinical-scale procedure to generate regulatory $\mathrm{T}$ cells from patients with amyotrophic lateral sclerosis for adoptive cell therapy. Cytotherapy. 2016 Oct;18(10):1312-24.

136 Keizman D, Rogowski O, Berliner S, IshShalom M, Maimon N, Nefussy B, et al. Lowgrade systemic inflammation in patients with amyotrophic lateral sclerosis. Acta Neurol Scand. 2009 Jun;119(6):383-9.
137 Hooten KG, Beers DR, Zhao W, Appel SH. Protective and Toxic Neuroinflammation in Amyotrophic Lateral Sclerosis. Neurotherapeutics. 2015 Apr;12(2):364-75.

138 Murdock BJ, Zhou T, Kashlan SR, Little RJ, Goutman SA, Feldman EL. Correlation of Peripheral Immunity With Rapid Amyotrophic Lateral Sclerosis Progression. JAMA Neurol. 2017 Dec;74(12):1446-54.

139 Rentzos M, Evangelopoulos E, Sereti E, Zouvelou V, Marmara S, Alexakis T, et al. Alterations of T cell subsets in ALS: a systemic immune activation? Acta Neurol Scand. 2012 Apr;125(4):260-4.

140 Finkelstein A, Kunis G, Seksenyan A, Ronen A, Berkutzki T, Azoulay D, et al. Abnormal changes in NKT cells, the IGF-1 axis, and liver pathology in an animal model of ALS. PLoS One. 2011;6(8):e22374.

141 Henkel JS, Beers DR, Wen S, Rivera AL, Toennis KM, Appel JE, et al. Regulatory Tlymphocytes mediate amyotrophic lateral sclerosis progression and survival. EMBO Mol Med. 2013 Jan;5(1):64-79.

142 Beers DR, Zhao W, Wang J, Zhang X, Wen $\mathrm{S}$, Neal D, et al. ALS patients' regulatory $\mathrm{T}$ lymphocytes are dysfunctional, and correlate with disease progression rate and severity. JCI Insight. 2017 Mar;2(5):e89530.

143 Kessler RC, Bromet EJ. The epidemiology of depression across cultures. Annu Rev Public Health. 2013;34(1):119-38.

144 Murray CJ, Atkinson C, Bhalla K, Birbeck G, Burstein R, Chou D, et al.; U.S. Burden of Disease Collaborators. The state of US health, 1990-2010: burden of diseases, injuries, and risk factors. JAMA. 2013 Aug; 310(6):591-608.

145 Krishnan V, Nestler EJ. The molecular neurobiology of depression. Nature. 2008 Oct; 455(7215):894-902.

146 Refojo D, Holsboer F. CRH signaling. Molecular specificity for drug targeting in the CNS. Ann N Y Acad Sci. 2009 Oct;1179(1): 106-19.

147 de Kloet ER, Joëls M, Holsboer F. Stress and the brain: from adaptation to disease. Nat Rev Neurosci. 2005 Jun;6(6):463-75.

148 Halldorsdottir T, Binder EB. Gene $\times$ Environment Interactions: From Molecular Mechanisms to Behavior. Annu Rev Psychol. 2017 Jan;68(1):215-41.

149 Heim C, Nemeroff CB. The role of childhood trauma in the neurobiology of mood and anxiety disorders: preclinical and clinical studies. Biol Psychiatry. 2001 Jun;49(12): 1023-39.

150 McEwen BS, Bowles NP, Gray JD, Hill MN, Hunter RG, Karatsoreos IN, et al. Mechanisms of stress in the brain. Nat Neurosci. 2015 Oct;18(10):1353-63.

151 Besedovsky HO, del Rey A. Immune-neuroendocrine interactions: facts and hypotheses. Endocr Rev. 1996 Feb;17(1):64-102.

152 Ashley NT, Demas GE. Neuroendocrineimmune circuits, phenotypes, and interactions. Horm Behav. 2017 Jan;87:25-34.
153 Danese A, J Lewis S. Psychoneuroimmunology of Early-Life Stress: The Hidden Wounds of Childhood Trauma? Neuropsychopharmacology. 2017 Jan;42(1):99-114.

154 Dinan TG, Cryan JF. Microbes, Immunity, and Behavior: Psychoneuroimmunology Meets the Microbiome. Neuropsychopharmacology. 2017 Jan;42(1):178-92.

155 Padro CJ, Sanders VM. Neuroendocrine regulation of inflammation. Semin Immunol. 2014 Oct;26(5):357-68.

156 Sperner-Unterweger B, Fuchs D. Schizophrenia and psychoneuroimmunology: an integrative view. Curr Opin Psychiatry. 2015 May;28(3):201-6.

157 Sternberg EM. Neural regulation of innate immunity: a coordinated nonspecific host response to pathogens. Nat Rev Immunol. 2006 Apr;6(4):318-28.

158 Haroon E, Raison CL, Miller AH. Psychoneuroimmunology meets neuropsychopharmacology: translational implications of the impact of inflammation on behavior. Neuropsychopharmacology. 2012 Jan;37(1): $137-62$.

159 Ménard C, Pfau ML, Hodes GE, Russo SJ. Immune and Neuroendocrine Mechanisms of Stress Vulnerability and Resilience. Neuropsychopharmacology. 2017 Jan;42(1):6280.

160 Wohleb ES, McKim DB, Sheridan JF, Godbout JP. Monocyte trafficking to the brain with stress and inflammation: a novel axis of immune-to-brain communication that influences mood and behavior. Front Neurosci. 2015 Jan;8:447.

161 Moussavi S, Chatterji S, Verdes E, Tandon A, Patel V, Ustun B. Depression, chronic diseases, and decrements in health: results from the World Health Surveys. Lancet. 2007 Sep;370(9590):851-8.

162 Maes M, Bosmans E, Suy E, Vandervorst C, DeJonckheere C, Raus J. Depression-related disturbances in mitogen-induced lymphocyte responses and interleukin-1 beta and soluble interleukin-2 receptor production. Acta Psychiatr Scand. 1991 Oct;84(4):37986.

163 Maes M, Lambrechts J, Bosmans E, Jacobs J, Suy E, Vandervorst C, et al. Evidence for a systemic immune activation during depression: results of leukocyte enumeration by flow cytometry in conjunction with monoclonal antibody staining. Psychol Med. 1992 Feb;22(1):45-53.

164 Maes M, Van der Planken M, Stevens WJ, Peeters D, DeClerck LS, Bridts $\mathrm{CH}$, et al. Leukocytosis, monocytosis and neutrophilia: hallmarks of severe depression. J Psychiatr Res. 1992 Apr;26(2):125-34.

165 Dowlati Y, Herrmann N, Swardfager W, Liu H, Sham L, Reim EK, et al. A meta-analysis of cytokines in major depression. Biol Psychiatry. 2010 Mar;67(5):446-57. 
166 Zorrilla EP, Luborsky L, McKay JR, Rosenthal R, Houldin A, Tax A, et al. The relationship of depression and stressors to immunological assays: a meta-analytic review. Brain Behav Immun. 2001 Sep;15(3):199-226.

167 Howren MB, Lamkin DM, Suls J. Associations of depression with C-reactive protein, IL-1, and IL-6: a meta-analysis. Psychosom Med. 2009 Feb;71(2):171-86

168 Fitzgerald P, O’Brien SM, Scully P, Rijkers K, Scott LV, Dinan TG. Cutaneous glucocorticoid receptor sensitivity and pro-inflammatory cytokine levels in antidepressant-resistant depression. Psychol Med. 2006 Jan; 36(1):37-43.

169 Lanquillon S, Krieg JC, Bening-Abu-Shach $\mathrm{U}$, Vedder $\mathrm{H}$. Cytokine production and treatment response in major depressive disorder. Neuropsychopharmacology. 2000 Apr;22(4):370-9.

170 Eller T, Vasar V, Shlik J, Maron E. Pro-inflammatory cytokines and treatment response to escitalopram in major depressive disorder. Prog Neuropsychopharmacol Biol Psychiatry. 2008 Feb;32(2):445-50.

171 Jazayeri S, Keshavarz SA, Tehrani-Doost M, Djalali M, Hosseini M, Amini H, et al. Effects of eicosapentaenoic acid and fluoxetine on plasma cortisol, serum interleukin-1beta and interleukin- 6 concentrations in patients with major depressive disorder. Psychiatry Res. 2010 Jun;178(1):112-5.

172 Maes M, Meltzer HY, Bosmans E, Bergmans $\mathrm{R}$, Vandoolaeghe E, Ranjan R, et al. Increased plasma concentrations of interleukin-6, soluble interleukin-6, soluble interleukin-2 and transferrin receptor in major depression. J Affect Disord. 1995 Aug;34(4): 301-9.

173 Bonfiglio JJ, Inda C, Senin S, Maccarrone G, Refojo D, Giacomini D, et al. B-Raf and CRHR1 internalization mediate biphasic ERK1/2 activation by CRH in hippocampal HT22 Cells. Mol Endocrinol. 2013 Mar; 27(3):491-510.

174 Sapolsky RM, Romero LM, Munck AU. How do glucocorticoids influence stress responses? Integrating permissive, suppressive, stimulatory, and preparative actions. Endocr Rev. 2000 Feb;21(1):55-89.

175 Silberstein S, Vogl AM, Bonfiglio JJ, Wurst W, Holsboer F, Arzt E, et al. Immunology, signal transduction, and behavior in hypothalamic-pituitary-adrenal axis-related genetic mouse models. Ann N Y Acad Sci. 2009 Feb;1153(1):120-30.

176 Katayama Y, Battista M, Kao WM, Hidalgo A, Peired AJ, Thomas SA, et al. Signals from the sympathetic nervous system regulate hematopoietic stem cell egress from bone marrow. Cell. 2006 Jan;124(2):407-21.

177 Spiegel A, Shivtiel S, Kalinkovich A, Ludin A, Netzer N, Goichberg P, et al. Catecholaminergic neurotransmitters regulate $\mathrm{mi}-$ gration and repopulation of immature human CD34+ cells through Wnt signaling. Nat Immunol. 2007 Oct;8(10):1123-31.
178 Dhabhar FS, Miller AH, McEwen BS, Spencer RL. Stress-induced changes in blood leukocyte distribution. Role of adrenal steroid hormones. J Immunol. 1996 Aug;157(4): 1638-44.

179 Sorrells SF, Caso JR, Munhoz CD, Sapolsky RM. The stressed CNS: when glucocorticoids aggravate inflammation. Neuron. 2009 Oct;64(1):33-9.

180 Besedovsky H, Sorkin E. Network of immune-neuroendocrine interactions. Clin Exp Immunol. 1977 Jan;27(1):1-12.

181 Besedovsky H, Sorkin E, Keller M, Müller J. Changes in blood hormone levels during the immune response. Proc Soc Exp Biol Med. 1975 Nov;150(2):466-70.

182 Munck A, Guyre PM, Holbrook NJ. Physiological functions of glucocorticoids in stress and their relation to pharmacological actions. Endocr Rev. 1984;5(1):25-44.

183 Tausk M. Hat die Nebenniere tatsächlich eine Verteidigungsfunktion? Das Hormon (Organon, Holland). 1951;3:1-24.

184 Holsboer F. The corticosteroid receptor hypothesis of depression. Neuropsychopharmacology. 2000 Nov;23(5):477-501.

185 Stetler C, Miller GE. Depression and hypothalamic-pituitary-adrenal activation: a quantitative summary of four decades of research. Psychosom Med. 2011 Feb-Mar; 73(2):114-26.

186 Henckens MJ, Deussing JM, Chen A. Region-specific roles of the corticotropin-releasing factor-urocortin system in stress. Nat Rev Neurosci. 2016 Oct;17(10):636-51.

187 Hoffmann A, Sportelli V, Ziller M, Spengler D. Epigenomics of Major Depressive Disorders and Schizophrenia: Early Life Decides. Int J Mol Sci. 2017 Aug; 18(8):18.

188 Anacker C, O’Donnell KJ, Meaney MJ. Early life adversity and the epigenetic programming of hypothalamic-pituitary-adrenal function. Dialogues Clin Neurosci. 2014 Sep;16(3):321-33.

189 Deussing JM, Jakovcevski M. Histone Modifications in Major Depressive Disorder and Related Rodent Models. Adv Exp Med Biol. 2017;978:169-83.

190 Klengel T, Binder EB. Epigenetics of StressRelated Psychiatric Disorders and Gene $\times$ Environment Interactions. Neuron. 2015 Jun;86(6):1343-57.

191 Weaver IC, Cervoni N, Champagne FA, D'Alessio AC, Sharma S, Seckl JR, et al. Epigenetic programming by maternal behavior. Nat Neurosci. 2004 Aug;7(8):847-54.

192 McGowan PO, Sasaki A, D’Alessio AC, Dymov S, Labonté B, Szyf M, et al. Epigenetic regulation of the glucocorticoid receptor in human brain associates with childhood abuse. Nat Neurosci. 2009 Mar; 12(3):342-8.

193 Klengel T, Mehta D, Anacker C, Rex-Haffner M, Pruessner JC, Pariante CM, et al. Allele-specific FKBP5 DNA demethylation mediates gene-childhood trauma interactions. Nat Neurosci. 2013 Jan;16(1):33-41.
194 Wochnik GM, Rüegg J, Abel GA, Schmidt U, Holsboer F, Rein T. FK506-binding proteins 51 and 52 differentially regulate dynein interaction and nuclear translocation of the glucocorticoid receptor in mammalian cells. J Biol Chem. 2005 Feb;280(6): 4609-16.

195 Denny WB, Prapapanich V, Smith DF, Scammell JG. Structure-function analysis of squirrel monkey FK506-binding protein 51, a potent inhibitor of glucocorticoid receptor activity. Endocrinology. 2005 Jul;146(7): 3194-201.

196 Barnes PJ, Adcock IM. Glucocorticoid resistance in inflammatory diseases. Lancet. 2009 May;373(9678):1905-17.

197 Liberman AC, Druker J, Garcia FA, Holsboer F, Arzt E. Intracellular molecular signaling. Basis for specificity to glucocorticoid anti-inflammatory actions. Ann N Y Acad Sci. 2009 Feb;1153(1):6-13.

198 Quan N, Avitsur R, Stark JL, He L, Lai W, Dhabhar F, et al. Molecular mechanisms of glucocorticoid resistance in splenocytes of socially stressed male mice. J Neuroimmunol. 2003 Apr;137(1-2):51-8.

199 Refojo D, Liberman AC, Giacomini D, Carbia Nagashima A, Graciarena M, Echenique $\mathrm{C}$, et al. Integrating systemic information at the molecular level: cross-talk between steroid receptors and cytokine signaling on different target cells. Ann N Y Acad Sci. 2003 May;992(1):196-204.

200 Engler H, Engler A, Bailey MT, Sheridan JF. Tissue-specific alterations in the glucocorticoid sensitivity of immune cells following repeated social defeat in mice. J Neuroimmunol. 2005 Jun;163(1-2):110-9.

201 Stark JL, Avitsur R, Padgett DA, Campbell KA, Beck FM, Sheridan JF. Social stress induces glucocorticoid resistance in macrophages. Am J Physiol Regul Integr Comp Physiol. 2001 Jun;280(6):R1799-805.

202 Trottier MD, Newsted MM, King LE, Fraker PJ. Natural glucocorticoids induce expansion of all developmental stages of murine bone marrow granulocytes without inhibiting function. Proc Natl Acad Sci USA. 2008 Feb;105(6):2028-33.

203 Miller GE, Chen E, Sze J, Marin T, Arevalo $\mathrm{JM}$, Doll R, et al. A functional genomic fingerprint of chronic stress in humans: blunted glucocorticoid and increased NF-kappaB signaling. Biol Psychiatry. 2008 Aug;64(4): 266-72.

204 Schoenfeld TJ, Cameron HA: Adult neurogenesis and mental illness. Neuropsychopharmacology. 2015;40(1):113-128.

205 Kheirbek MA, Klemenhagen KC, Sahay A, Hen R. Neurogenesis and generalization: a new approach to stratify and treat anxiety disorders. Nat Neurosci. 2012 Dec;15(12): 1613-20.

206 Sahay A, Hen R. Adult hippocampal neurogenesis in depression. Nat Neurosci. 2007 Sep;10(9):1110-5. 
207 Sorrells SF, Paredes MF, Cebrian-Silla A, Sandoval K, Qi D, Kelley KW, et al. Human hippocampal neurogenesis drops sharply in children to undetectable levels in adults. $\mathrm{Na}$ ture. 2018 Mar;555(7696):377-81.

208 Kempermann G, Gage FH, Aigner L, Song H, Curtis MA, Thuret S, et al. Human Adult Neurogenesis: Evidence and Remaining Questions. Cell Stem Cell. 2018 Jul;23(1):25-30.

209 Boldrini M, Fulmore CA, Tartt AN, Simeon LR, Pavlova I, Poposka V, Rosoklija GB, Stankov A, Arango V, Dwork AJ, Hen R, Mann JJ: Human Hippocampal Neurogenesis Persists throughout Aging. Cell Stem Cell. 2018;22(4):589-599 e585.

210 Smith MA, Makino S, Kvetnansky R, Post RM. Stress and glucocorticoids affect the expression of brain-derived neurotrophic factor and neurotrophin-3 mRNAs in the hippocampus. J Neurosci. 1995 Mar;15(3 Pt 1): 1768-77.

211 Rasmusson AM, Shi L, Duman R: Downregulation of BDNF mRNA in the hippocampal dentate gyrus after re-exposure to cues previously associated with footshock. Neuropsychopharmacology. 2002;27(2):133-142.

212 Ueyama T, Kawai Y, Nemoto K, Sekimoto M, Toné S, Senba E. Immobilization stress reduced the expression of neurotrophins and their receptors in the rat brain. Neurosci Res. 1997 Jun;28(2):103-10.

213 Roceri M, Hendriks W, Racagni G, Ellenbroek BA, Riva MA. Early maternal deprivation reduces the expression of BDNF and NMDA receptor subunits in rat hippocampus. Mol Psychiatry. 2002;7(6):609-16.

214 Chao HM, Sakai RR, Ma LY, McEwen BS. Adrenal steroid regulation of neurotrophic factor expression in the rat hippocampus. Endocrinology. 1998 Jul;139(7):3112-8.

215 Schaaf MJ, de Jong J, de Kloet ER, Vreugdenhil E. Downregulation of BDNF mRNA and protein in the rat hippocampus by corticosterone. Brain Res. 1998 Nov;813(1):112-20.

216 Tsankova NM, Berton O, Renthal W, Kumar A, Neve RL, Nestler EJ. Sustained hippocampal chromatin regulation in a mouse model of depression and antidepressant action. Nat Neurosci. 2006 Apr;9(4):519-25.

217 Dwivedi Y, Rizavi HS, Pandey GN. Antidepressants reverse corticosterone-mediated decrease in brain-derived neurotrophic factor expression: differential regulation of specific exons by antidepressants and corticosterone. Neuroscience. 2006;139(3):1017-29.

218 MacQueen GM, Ramakrishnan K, Croll SD, Siuciak JA, Yu G, Young LT, et al. Performance of heterozygous brain-derived neurotrophic factor knockout mice on behavioral analogues of anxiety, nociception, and depression. Behav Neurosci. 2001 Oct; 115(5):1145-53.

219 Zörner B, Wolfer DP, Brandis D, Kretz O, Zacher C, Madani R, et al. Forebrain-specific trkB-receptor knockout mice: behaviorally more hyperactive than "depressive". Biol Psychiatry. 2003 Nov;54(10):972-82.
220 Monteggia LM, Barrot M, Powell CM, Berton O, Galanis V, Gemelli T, et al. Essential role of brain-derived neurotrophic factor in adult hippocampal function. Proc Natl Acad Sci USA. 2004 Jul;101(29):10827-32.

221 Saarelainen T, Hendolin P, Lucas G, Koponen E, Sairanen M, MacDonald E, et al. Activation of the TrkB neurotrophin receptor is induced by antidepressant drugs and is required for antidepressant-induced behavioral effects. J Neurosci. 2003 Jan;23(1):34957.

222 Castrén E, Võikar V, Rantamäki T. Role of neurotrophic factors in depression. Curr Opin Pharmacol. 2007 Feb;7(1):18-21.

223 Chapman TR, Barrientos RM, Ahrendsen JT, Hoover JM, Maier SF, Patterson SL: Aging and infection reduce expression of specific brain-derived neurotrophic factor mRNAs in hippocampus. Neurobiol Aging 2012;33(4):832 e831-814.

224 Guan Z, Fang J. Peripheral immune activation by lipopolysaccharide decreases neurotrophins in the cortex and hippocampus in rats. Brain Behav Immun. 2006 Jan;20(1): 64-71.

225 Lapchak PA, Araujo DM, Hefti F. Systemic interleukin-1 beta decreases brain-derived neurotrophic factor messenger RNA expression in the rat hippocampal formation. Neuroscience. 1993 Mar;53(2):297-301.

226 Felten DL, Felten SY, Carlson SL, Olschowka JA, Livnat S. Noradrenergic and peptidergic innervation of lymphoid tissue. J Immunol. 1985 Aug;135(2 Suppl):755s-65s.

227 Heidt T, Sager HB, Courties G, Dutta P, Iwamoto Y, Zaltsman A, et al. Chronic variable stress activates hematopoietic stem cells. Nat Med. 2014 Jul;20(7):754-8.

228 Powell ND, Sloan EK, Bailey MT, Arevalo JM, Miller GE, Chen E, et al. Social stress upregulates inflammatory gene expression in the leukocyte transcriptome via $\beta$-adrenergic induction of myelopoiesis. Proc Natl Acad Sci USA. 2013 Oct;110(41):16574-9.

229 Heim C, Shugart M, Craighead WE, Nemeroff CB. Neurobiological and psychiatric consequences of child abuse and neglect. Dev Psychobiol. 2010 Nov;52(7):671-90.

230 Chen E, Miller GE, Kobor MS, Cole SW. Maternal warmth buffers the effects of low early-life socioeconomic status on pro-inflammatory signaling in adulthood. Mol Psychiatry. 2011 Jul;16(7):729-37.

231 Danese A, Pariante CM, Caspi A, Taylor A, Poulton R. Childhood maltreatment predicts adult inflammation in a life-course study. Proc Natl Acad Sci USA. 2007 Jan; 104(4):1319-24.

232 Pace TW, Mletzko TC, Alagbe O, Musselman DL, Nemeroff CB, Miller AH, et al. Increased stress-induced inflammatory responses in male patients with major depression and increased early life stress. Am J Psychiatry. 2006 Sep;163(9):1630-3.
233 Khandaker GM, Pearson RM, Zammit S, Lewis G, Jones PB. Association of serum interleukin 6 and C-reactive protein in childhood with depression and psychosis in young adult life: a population-based longitudinal study. JAMA Psychiatry. 2014 Oct; 71(10):1121-8.

234 Wohleb ES, Hanke ML, Corona AW, Powell ND, Stiner LM, BaileyMT, etal. $\beta$-Adrenergic receptor antagonism prevents anxiety-like behavior and microglial reactivity induced by repeated social defeat. J Neurosci. 2011 Apr;31(17):6277-88.

235 Wohleb ES, Patterson JM, Sharma V, Quan N, Godbout JP, Sheridan JF. Knockdown of interleukin-1 receptor type-1 on endothelial cells attenuated stress-induced neuroinflammation and prevented anxiety-like behavior. J Neurosci. 2014 Feb;34(7):2583-91.

236 Wohleb ES, Powell ND, Godbout JP, Sheridan JF. Stress-induced recruitment of bone marrow-derived monocytes to the brain promotes anxiety-like behavior. J Neurosci. 2013 Aug;33(34):13820-33.

237 Torres-Platas SG, Cruceanu C, Chen GG, Turecki G, Mechawar N. Evidence for increased microglial priming and macrophage recruitment in the dorsal anterior cingulate white matter of depressed suicides. Brain Behav Immun. 2014 Nov;42:50-9.

238 Ransohoff RM, Tani M. Do chemokines mediate leukocyte recruitment in post-traumatic CNS inflammation? Trends Neurosci. 1998 Apr;21(4):154-9.

239 Panenka W, Jijon H, Herx LM, Armstrong JN, Feighan D, Wei T, et al. P2X7-like receptor activation in astrocytes increases chemokine monocyte chemoattractant protein-1 expression via mitogen-activated protein $\mathrm{ki}$ nase. J Neurosci. 2001 Sep;21(18):7135-42.

240 Barden N, Harvey M, Gagné B, Shink E, Tremblay M, Raymond C, et al. Analysis of single nucleotide polymorphisms in genes in the chromosome 12Q24.31 region points to P2RX7 as a susceptibility gene to bipolar affective disorder. Am J Med Genet B Neuropsychiatr Genet. 2006 Jun;141B(4):374-82.

241 Lucae S, Salyakina D, Barden N, Harvey M, Gagné B, Labbé M, et al. P2RX7, a gene coding for a purinergic ligand-gated ion channel, is associated with major depressive disorder. Hum Mol Genet. 2006 Aug;15(16): 2438-45.

242 Aprile-Garcia F, Metzger MW, Paez-Pereda M, Stadler H, Acuña M, Liberman AC, et al. Co-Expression of Wild-Type P2X7R with Gln460Arg Variant Alters Receptor Function. PLoS One. 2016 Mar;11(3): e0151862.

243 Metzger MW, Walser SM, Dedic N, AprileGarcia F, Jakubcakova V, Adamczyk M, et al Heterozygosity for the Mood Disorder-Associated Variant Gln460Arg Alters P2X7 Receptor Function and Sleep Quality. J Neurosci. 2017 Nov;37(48):11688-700. 
244 Iwata M, Ota KT, Li XY, Sakaue F, Li N, Dutheil S, et al. Psychological Stress Activates the Inflammasome via Release of Adenosine Triphosphate and Stimulation of the Purinergic Type 2X7 Receptor. Biol Psychiatry. 2016 Jul;80(1):12-22.

245 Nagy C, Suderman M, Yang J, Szyf M, Mechawar N, Ernst C, et al. Astrocytic abnormalities and global DNA methylation patterns in depression and suicide. Mol Psychiatry. 2015 Mar;20(3):320-8.

246 Torres-Platas SG, Nagy C, Wakid M, Turecki G, Mechawar N. Glial fibrillary acidic protein is differentially expressed across cortical and subcortical regions in healthy brains and downregulated in the thalamus and caudate nucleus of depressed suicides. Mol Psychiatry. 2016 Apr;21(4):509-15.

247 Tynan RJ, Beynon SB, Hinwood M, Johnson SJ, Nilsson M, Woods JJ, et al. Chronic stress-induced disruption of the astrocyte network is driven by structural atrophy and not loss of astrocytes. Acta Neuropathol. 2013 Jul;126(1):75-91.

248 Tynan RJ, Naicker S, Hinwood M, Nalivaiko E, Buller KM, Pow DV, et al. Chronic stress alters the density and morphology of microglia in a subset of stress-responsive brain regions. Brain Behav Immun. 2010 Oct; 24(7):1058-68.

249 Wohleb ES, Franklin T, Iwata M, Duman RS. Integrating neuroimmune systems in the neurobiology of depression. Nat Rev Neurosci. 2016 Aug;17(8):497-511.

250 Weber MD, Frank MG, Tracey KJ, Watkins LR, Maier SF. Stress induces the danger-associated molecular pattern HMGB-1 in the hippocampus of male Sprague Dawley rats: a priming stimulus of microglia and the NLRP3 inflammasome. J Neurosci. 2015 Jan;35(1):316-24.

251 Kreisel T, Frank MG, Licht T, Reshef R, BenMenachem-Zidon O, Baratta MV, et al. Dynamic microglial alterations underlie stressinduced depressive-like behavior and suppressed neurogenesis. Mol Psychiatry. 2014 Jun;19(6):699-709.

252 Milior G, Lecours C, Samson L, Bisht K, Poggini S, Pagani F, et al. Fractalkine receptor deficiency impairs microglial and neuronal responsiveness to chronic stress. Brain Behav Immun. 2016 Jul;55:114-25.

253 Schafer DP, Lehrman EK, Kautzman AG, Koyama R, Mardinly AR, Yamasaki R, et al. Microglia sculpt postnatal neural circuits in an activity and complement-dependent manner. Neuron. 2012 May;74(4):691-705.

254 Steiner J, Walter M, Gos T, Guillemin GJ, Bernstein HG, Sarnyai Z, et al. Severe depression is associated with increased microglial quinolinic acid in subregions of the anterior cingulate gyrus: evidence for an immune-modulated glutamatergic neurotransmission? J Neuroinflammation. 2011 Aug;8(1):94.
255 Setiawan E, Wilson AA, Mizrahi R, Rusjan PM, Miler L, Rajkowska G, et al. Role of translocator protein density, a marker of neuroinflammation, in the brain during major depressive episodes. JAMA Psychiatry. 2015 Mar;72(3):268-75.

256 Müller N, Schwarz MJ, Dehning S, Douhe A, Cerovecki A, Goldstein-Müller B, et al. The cyclooxygenase-2 inhibitor celecoxib has therapeutic effects in major depression: results of a double-blind, randomized, placebo controlled, add-on pilot study to reboxetine. Mol Psychiatry. 2006 Jul;11(7):680-4.

257 Warner-Schmidt JL, Vanover KE, Chen EY, Marshall JJ, Greengard P. Antidepressant effects of selective serotonin reuptake inhibitors (SSRIs) are attenuated by antiinflammatory drugs in mice and humans. Proc Natl Acad Sci USA. 2011 May;108(22):9262-7.

258 Köhler O, Benros ME, Nordentoft M, Farkouh ME, Iyengar RL, Mors O, et al. Effect of anti-inflammatory treatment on depression, depressive symptoms, and adverse effects: a systematic review and meta-analysis of randomized clinical trials. JAMA Psychiatry. 2014 Dec;71(12):1381-91.

259 Raison CL, Rutherford RE, Woolwine BJ, Shuo C, Schettler P, Drake DF, et al. A randomized controlled trial of the tumor necrosis factor antagonist infliximab for treatment-resistant depression: the role of baseline inflammatory biomarkers. JAMA Psychiatry. 2013 Jan;70(1):31-41.

260 Friedle SA, Curet MA, Watters JJ. Recent patents on novel $\mathrm{P} 2 \mathrm{X}(7)$ receptor antagonists and their potential for reducing central nervous system inflammation. Recent Patents CNS Drug Discov. 2010 Jan;5(1):35-45.

261 Gadient RA, Otten U. Expression of interleukin-6 (IL-6) and interleukin-6 receptor (IL-6R) mRNAs in rat brain during postnatal development. Brain Res. 1994 Feb;637(12):10-4.

262 Hallmayer J, Cleveland S, Torres A, Phillips J, Cohen B, Torigoe T, et al. Genetic heritability and shared environmental factors among twin pairs with autism. Arch Gen Psychiatry. 2011 Nov;68(11):1095-102.

263 Patterson PH. Immune involvement in schizophrenia and autism: etiology, pathology and animal models. Behav Brain Res. 2009 Dec;204(2):313-21.

264 Ruff JS, Nelson AC, Kubinak JL, Potts WK. MHC signaling during social communication. Adv Exp Med Biol. 2012;738:290-313.

265 Sturm T, Leinders-Zufall T, Maček B, Walzer M, Jung S, Pömmerl B, et al. Mouse urinary peptides provide a molecular basis for genotype discrimination by nasal sensory neurons. Nat Commun. 2013;4(1):1616.

266 Hsiao EY, Patterson PH. Placental regulation of maternal-fetal interactions and brain development. Dev Neurobiol. 2012 Oct; 72(10):1317-26.
267 Bakken TE, Miller JA, Ding SL, Sunkin SM, Smith KA, Ng L, et al. A comprehensive transcriptional map of primate brain development. Nature. 2016 Jul;535(7612):36775.

268 Budday S, Steinmann P, Kuhl E. The role of mechanics during brain development. J Mech Phys Solids. 2014 Dec;72:75-92.

269 Budday S, Steinmann P, Kuhl E. Physical biology of human brain development. Front Cell Neurosci. 2015 Jul;9:257.

270 Gomes da Silva S, Arida RM. Physical activity and brain development. Expert Rev Neurother. 2015;15(9):1041-51.

271 Jansen AG, Mous SE, White T, Posthuma D, Polderman TJ. What twin studies tell us about the heritability of brain development, morphology, and function: a review. Neuropsychol Rev. 2015 Mar;25(1):27-46.

272 Kasper C, Vierbuchen M, Ernst U, Fischer S, Radersma R, Raulo A, et al. Genetics and developmental biology of cooperation. $\mathrm{Mol}$ Ecol. 2017 Sep;26(17):4364-77.

273 Ocklenburg S, Schmitz J, Moinfar Z, Moser D, Klose R, Lor S, et al. Epigenetic regulation of lateralized fetal spinal gene expression underlies hemispheric asymmetries. eLife. 2017 Feb;6:6.

274 Popovitchenko T, Rasin MR. Transcriptional and Post-Transcriptional Mechanisms of the Development of Neocortical Lamination. Front Neuroanat. 2017 Nov; 11:102.

275 Kolb B, Harker A, Gibb R. Principles of plasticity in the developing brain. Dev Med Child Neurol. 2017 Dec;59(12):1218-23.

276 Kundakovic M, Jaric I. The Epigenetic Link between Prenatal Adverse Environments and Neurodevelopmental Disorders. Genes (Basel). 2017 Mar;8(3):8.

277 Lv JW, Cheng TL, Qiu ZL, Zhou WH. Role of the PTEN signaling pathway in autism spectrum disorder. Neurosci Bull. 2013 Dec; 29(6):773-8.

278 Lyu JW, Yuan B, Cheng TL, Qiu ZL, Zhou $\mathrm{WH}$. Reciprocal regulation of autism-related genes MeCP2 and PTEN via microRNAs. Sci Rep. 2016 Feb;6(1):20392.

279 Nicolini C, Ahn Y, Michalski B, Rho JM, Fahnestock M. Decreased mTOR signaling pathway in human idiopathic autism and in rats exposed to valproic acid. Acta Neuropathol Commun. 2015 Jan;3(1):3.

280 Chomiak T, Hu B. Alterations of neocortical development and maturation in autism: insight from valproic acid exposure and animal models of autism. Neurotoxicol Teratol. 2013 Mar-Apr;36:57-66.

281 Nagode DA, Meng X, Winkowski DE, Smith E, Khan-Tareen H, Kareddy V, et al. Abnormal Development of the Earliest Cortical Circuits in a Mouse Model of Autism Spectrum Disorder. Cell Reports. 2017 Jan; 18(5): $1100-8$. 
282 Gottfried C, Bambini-Junior V, Francis F, Riesgo R, Savino W. The Impact of Neuroimmune Alterations in Autism Spectrum Disorder. Front Psychiatry. 2015 Sep;6:121.

283 Chess S. Autism in children with congenital rubella. J Autism Child Schizophr. 1971 JanMar;1(1):33-47.

284 Bilbo SD, Block CL, Bolton JL, Hanamsagar $\mathrm{R}$, Tran PK. Beyond infection - Maternal immune activation by environmental factors, microglial development, and relevance for autism spectrum disorders. Exp Neurol. 2018 Jan;299 Pt A:241-51.

285 Careaga M, Murai T, Bauman MD. Maternal Immune Activation and Autism Spectrum Disorder: From Rodents to Nonhuman and Human Primates. Biol Psychiatry. 2017 Mar; 81(5):391-401.

286 McAllister AK. Immune Contributions to Cause and Effect in Autism Spectrum Disorder. Biol Psychiatry. 2017 Mar;81(5):380-2.

287 Meltzer A, Van de Water J. The Role of the Immune System in Autism Spectrum Disorder. Neuropsychopharmacology. 2017 Jan; 42(1):284-98

288 Garay PA, Hsiao EY, Patterson PH, McAllister AK. Maternal immune activation causes age- and region-specific changes in brain cytokines in offspring throughout development. Brain Behav Immun. 2013 Jul; 31:54-68.

289 Garbett KA, Hsiao EY, Kálmán S, Patterson $\mathrm{PH}$, Mirnics K. Effects of maternal immune activation on gene expression patterns in the fetal brain. Transl Psychiatry. 2012 Apr; 2(4):e98.

290 Lombardo MV, Moon HM, Su J, Palmer TD, Courchesne E, Pramparo T. Maternal immune activation dysregulation of the fetal brain transcriptome and relevance to the pathophysiology of autism spectrum disorder. Mol Psychiatry. 2018 Apr;23(4):100113.

291 Rose DR, Careaga M, Van de Water J, McAllister K, Bauman MD, Ashwood P. Longterm altered immune responses following fetal priming in a non-human primate model of maternal immune activation. Brain Behav Immun. 2017 Jul;63:60-70.

292 Custódio CS, Mello BS, Filho AJ, de Carvalho Lima CN, Cordeiro RC, Miyajima F, et al. Neonatal Immune Challenge with Lipopolysaccharide Triggers Long-lasting Sexand Age-related Behavioral and Immune/ Neurotrophic Alterations in Mice: Relevance to Autism Spectrum Disorders. Mol Neurobiol. 2018 May;55(5):3775-88.
293 Hull L, Mandy W, Petrides KV. Behavioural and cognitive sex/gender differences in autism spectrum condition and typically developing males and females. Autism. 2017 Aug; 21(6):706-27.

294 Lai MC, Baron-Cohen S, Buxbaum JD. Understanding autism in the light of sex/gender. Mol Autism. 2015 May;6(1):24.

295 Masi A, Glozier N, Dale R, Guastella AJ. The Immune System, Cytokines, and Biomarkers in Autism Spectrum Disorder. Neurosci Bull. 2017 Apr;33(2):194-204.

296 Krakowiak P, Goines PE, Tancredi DJ, Ashwood P, Hansen RL, Hertz-Picciotto I, et al. Neonatal Cytokine Profiles Associated With Autism Spectrum Disorder. Biol Psychiatry. 2017 Mar;81(5):442-51.

297 Koyama R, Ikegaya Y. Microglia in the pathogenesis of autism spectrum disorders. Neurosci Res. 2015 Nov; 100:1-5.

298 Petrelli F, Pucci L, Bezzi P. Astrocytes and Microglia and Their Potential Link with Autism Spectrum Disorders. Front Cell Neurosci. 2016 Feb; 10:21.

299 Zeidán-Chuliá F, Salmina AB, Malinovskaya NA, Noda M, Verkhratsky A, Moreira JC. The glial perspective of autism spectrum disorders. Neurosci Biobehav Rev. 2014 Jan;38: $160-72$.

300 Amaral DG, Schumann CM, Nordahl CW. Neuroanatomy of autism. Trends Neurosci. 2008 Mar;31(3):137-45.

301 Shigemori T, Sakai A, Takumi T, Itoh Y, Suzuki H. Altered Microglia in the Amygdala Are Involved in Anxiety-related Behaviors of a Copy Number Variation Mouse Model of Autism. J Nippon Med Sch. 2015;82(2): 92-9.

302 Roullet FI, Lai JK, Foster JA. In utero exposure to valproic acid and autism-a current review of clinical and animal studies. Neurotoxicol Teratol. 2013 Mar-Apr;36:47-56.

303 Bromley RL, Mawer GE, Briggs M, Cheyne C, Clayton-Smith J, García-Fiñana M, et al.; Liverpool and Manchester Neurodevelopment Group. The prevalence of neurodevelopmental disorders in children prenatally exposed to antiepileptic drugs. J Neurol Neurosurg Psychiatry. 2013 Jun;84(6):63743.

304 Ferstl R, Akdis CA, O’Mahony L. Histamine regulation of innate and adaptive immunity. Front Biosci. 2012 Jan;17(1):40-53.

305 Haas HL, Sergeeva OA, Selbach O. Histamine in the nervous system. Physiol Rev. 2008 Jul;88(3):1183-241.
306 Baronio D, Castro K, Gonchoroski T, de Melo GM, Nunes GD, Bambini-Junior V, et al. Effects of an H3R antagonist on the animal model of autism induced by prenatal exposure to valproic acid. PLoS One. 2015 Jan; 10(1):e0116363.

307 Elmer BM, McAllister AK. Major histocompatibility complex class I proteins in brain development and plasticity. Trends Neurosci. 2012 Nov;35(11):660-70.

308 Shatz CJ. MHC class I: an unexpected role in neuronal plasticity. Neuron. 2009 Oct;64(1): $40-5$.

309 Pribiag H, Stellwagen D. Neuroimmune regulation of homeostatic synaptic plasticity. Neuropharmacology. 2014 Mar;78:13-22.

310 Mosser CA, Baptista S, Arnoux I, Audinat E. Microglia in CNS development: shaping the brain for the future. Prog Neurobiol. 2017 Feb-Mar; 149-150:1-20.

311 Arcuri C, Mecca C, Bianchi R, Giambanco I, Donato R. The Pathophysiological Role of Microglia in Dynamic Surveillance, Phagocytosis and Structural Remodeling of the Developing CNS. Front Mol Neurosci. 2017 Jun; 10:191.

312 Kim HJ, Cho MH, Shim WH, Kim JK, Jeon EY, Kim DH, Yoon SY: Deficient autophagautophagy in microglia impairs synaptic pruning and causes social behavioral defects. Mol Psychiatry. 2017;22:1576-1584.

313 Mizoguchi Y, Monji A: Microglial Intracellular $\mathrm{Ca}(2+)$ Signaling in Synaptic Development and its Alterations in Neurodevelopmental Disorders. Front Cell Neurosci. 2017;11:69.

314 Salter MW, Beggs S: Sublime microglia: expanding roles for the guardians of the CNS. Cell. 2014;158:15-24

315 Guadagno J, Swan P, Shaikh R, Cregan SP: Microglia-derived IL-1beta triggers p53mediated cell cycle arrest and apoptosis in neural precursor cells. Cell Death Dis. 2015; 6:e1779.

316 Lee AS, Azmitia EC, Whitaker-Azmitia PM Developmental microglial priming in postmortem autism spectrum disorder temporal cortex. Brain Behav Immun. 2017;62:193202.

317 Huang Z, Zang K, Reichardt LF: The origin recognition core complex regulates dendrite and spine development in postmitotic neurons. J Cell Biol. 2005;170:527-535.

318 Lim S, Kaldis P: Cdks, cyclins and CKIs: roles beyond cell cycle regulation. Development (Cambridge). 2013;140:3079-3093.

319 Su SC, Tsai LH: Cyclin-dependent kinases in brain development and disease. Annu Rev Cell Dev Biol. 2011;27:465-491 